\title{
IMÁGENES DE INDÍGENAS CON PASAPORTE ABIERTO: DEL GRAN CHACO A TIERRA DEL FUEGO ${ }^{1}$
}

\author{
MARGARITA ALVARADO* Y MARIANA GIORDANO"
}

\begin{abstract}
RESUMEN
Este trabajo tiene como objetivo principal exponer las reflexiones y análisis de un conjunto de fotografías de fines del siglo XIX y comienzos del siglo XX, de realidades culturales muy distantes geográficamente - región del Gran Chaco y la zona de Tierra del Fuego (América del Sur) - pero cercanas en cuanto a sus formas de producción e interpretación de lo visible. Nuestra hipótesis es que a partir de un conjunto de imágenes de indígenas sometidos a lo que hemos llamado una "trashumancia iconográfica", se ha contribuido a moldear e influir en la construcción de identidades étnicas y sociales con relación a lo llamado "chaqueño" y "fueguino". Planteamos que las maneras en que se ha definido la "otredad" visual de estos grupos están sometidas a ciertos mecanismos de construcción e interpretación de identidades y etnicidades, así como también de transmisión de memorias pre-moldeadas, en donde se manifiestan características visuales específicas para organizar la diferencia y por lo tanto las formas de "imaginarizarlas". La fotografía puede ser pensada como una producción cultural donde la memoria social o colectiva busca referentes, huellas y marcos de contención. Estas imágenes constituyen memorias delineadas sobre el "otro" en espacios disímiles pero que han sido intercambiados por la circulación que se les ha dado.
\end{abstract}

PALABRAS CLAVES: Fotografía, indígenas, Gran Chaco, Tierra del Fuego, identidad étnica.

\section{IMAGES OF NATIVES WITH AN OPEN PASSPORT: FROM GRAN CHACO TO TIERRA DEL FUEGO}

\footnotetext{
ABSTRACT

This work is devoted to expound the thoughts and analyses we have been carrying out from a group of photographs of the late $\mathrm{XIX}^{\text {th }}$ and early $\mathrm{XX}^{\text {th }}$ centuries, which show two cultural realities that, though extremely distant if

1 Un análisis preliminar de este trabajo fue presentado como ponencia al VI Congreso Internacional de Etnohistoria, Buenos Aires, 2005 bajo el título "Trashumancia iconográfica: del Chaco a Tierra del Fuego". Este trabajo forma parte de los proyectos Fotografías del fin del mundo. Construcción imaginaria del indígena fueguino como sujeto histórico (1880 - 1930), (Fondecyt 1030979) y La construcción de un imaginario sobre el indígena chaqueño. Un siglo de enfoques fotográficos (Proyecto Im40-246-ANPCYT).

- Instituto de Estética. Pontificia Universidad Católica. Av. Jaime Guzmán № 3300, Providencia, Santiago, CHILE. Email: malvarap@puc.cl

** Instituto de Investigaciones Geohistóricas-CONICET. Av. Castelli 930, CP3500, Resistencia, Chaco, ARGENTINA. Email: marianagfav@ciudad.com.ar
} 
seen from a geographical point of view, are really close if focused from their ways of producing and interpreting the visible world. Our hypothesis is that, thanks to a group of images of natives that were subjected to what we have called 'an iconographic transhumance', there has been a contribution to the modelling and construction of the ethnic and social identities regarding the so-called 'Chaqueño' and 'Fueguino' natives. We state that the ways in which the visual 'otherness' of these groups have been defined are subjected to certain mechanisms of construction and interpretation of identities and ethnicities, as well as to others of transmission of pre-moulded memories, in which certain specific visual features become manifest in order to organize the difference and, thus, the ways of 'imaginaryzing' them. Photography can be thought of as a cultural production where the social or collective memory looks for referents, traces, and retaining frameworks. These images are memories that were outlined over the 'other' within dissimilar spaces, which have nonetheless been interchanged through the circulation they have been subdued to.

KEY WORDS: Photography, natives, Gran Chaco, Tierra del Fuego, ethnic identity.

\section{PRESENTACIÓN}

Las formas de "ver" las fotografías por los historiadores, antropólogos y cientistas sociales en general han cambiado sustancialmente desde fines de la década de 1960; aquellas dejaron de ser consideradas solamente como una estrategia de registro y documentación visual de una situación encontrada en la "realidad", para transformarse en una temática por sí mismas. Parte de estos avances - por decirlo de alguna manera - se debe fundamentalmente a que la fotografía ya no es sólo considerada como producto de la técnica, entendida como un conjunto de conocimientos teóricos aplicados para producir una imagen susceptible de ser almacenada y reproducida (Burke 2001). Actualmente, los múltiples enfoques sobre el acto fotográfico, lo fotografiado y la imagen fotográfica como artefacto cultural y sistema convencionalizado de representación, consideran estrategias de análisis y marcos teóricos tan amplios y diversos, que las posibilidades de lectura e interpretación de esta expresión visual han llegado a expandirse de una manera insospechada ${ }^{2}$.

Estos planteamientos resultan especialmente atingentes para el estudio y reflexión en relación a aquellas fotografías que contienen imágenes y tomas de diferentes pueblos y culturas "nativas", sobre todo de América y África, que hoy se con-

2 Un interesante y completo análisis sobre estos aspectos se encuentra en el texto "Más allá del referente, fotografía. Del index a la palabra" (Concha 2004). También se pueden consultar los clásicos textos de Barthes (1982); Batchen (2004); Dubois (1994); Flusser (1990); Samuel (2000), entre otros. sideran extintas o profundamente transculturadas. La relación entre fotografía y antropología establecida desde los inicios de ambas prácticas ha sido abordada bajo estas nuevas perspectivas, resultando pionero en este sentido el texto "Anthropology \& Photography. 1860 -1920" (Edwards, 1992) donde a través de distintos artículos se problematiza no sólo en cuanto a la fotografía como registro de realidades culturales diferentes, sino que se intenta un abordaje que dé cuenta de las complejidades de la imagen como lenguaje y como representación.

En Argentina y Chile, diversos profesionales han abordado también estas temáticas de la imagen, la antropología y la historia bajo diversos marcos teóricos y estrategias de análisis. Entre los trabajos pioneros más relevantes podemos mencionar para Argentina a Marta Penhos (1995 a y b); Julio Vezub (2002), Carlos Masotta (2001) y para Chile Daniel Quiroz (1993); Sonia Montecinos, Rolf Foester y Angélica Wilson (1993), entre otros ${ }^{3}$.

Siguiendo estos planteamientos, el presente trabajo tiene como objetivo principal exponer aspectos de una metodología bajo la cual hemos llevado a cabo ciertas reflexiones y análisis de un conjunto de fotografías de realidades culturales muy distantes geográficamente, pero cercanas en cuanto a sus formas de producción e interpretación de lo visible. Nos referimos a diversas fotografías tomadas, más o menos en la misma época - fines del siglo XIX /comienzos del siglo XX - en la región

3 A estos trabajos se deben agregar los realizados por Alvarado (2000, 2001a, 2001b y 2005) y Giordano (2002, 2003 y 2004) que también en su momento aportaron a estos pioneros estudios. 
del Gran Chaco y la zona de Tierra del Fuego, en el continente sudamericano ${ }^{4}$.

A través de esta reflexión se busca demostrar cómo estas imágenes sometidas a lo que hemos denominado una "trashumancia iconográfica", han contribuido a moldear y muchas veces han influido directamente en la construcción de identidades étnicas y sociales específicas, en relación a lo llamado "chaquense" y "fueguino". Planteamos que las maneras en que se ha definido la "otredad" visual de estos grupos están sometidas a ciertos mecanismos de construcción e interpretación de identidades y etnicidades, y de transmisión de imaginarios premoldeados en donde se manifiestan características visuales específicas para organizar la diferencia y por lo tanto, diversas formas de "imaginarizarlas". La fotografía puede ser pensada como un espacio de "rememorización", donde lo social o colectivo busca referentes, marcas y marcos de contención (Bauret 1999). Estas imágenes constituyen recuerdos delineados sobre el "otro" en espacios disímiles de nuestro continente americano, pero que han sido intercambiados por la descripción y circulación que se les ha dado en diferentes contextos iconográficos. Espacio y sujeto representado han pasado a conformar parte del imaginario colectivo, y es nuestro objetivo indagar sobre las maneras en que esos espacios y sujetos han sido observados, modelados y manipulados, creando así diversas imágenes de lo chaquense y lo fueguino.

Así, sostenemos que ciertas fotografías de los grupos originarios del Gran Chaco y de Tierra del Fuego consideradas como imagen, han contribuido a una visión genérica construida, básicamente, según el eje opositor civilización/barbarie. De esta manera, la imagen fotográfica se ha constituido en referente para confirmar esta oposición en diversos contextos iconográficos, más que como fuente para el establecimiento visual e interpretación de ciertas identidades.

4 El Gran Chaco comprende una amplia región que abarca el oeste del Paraguay, el sur este de Bolivia y el noreste de Argentina (actuales provincias de Chaco y Formosa, suroeste de Salta y norte de Santa Fe). La Tierra del Fuego comprende una región que incluye toda la isla grande, tanto a zona chilena como la argentina y los canales e islas que la rodean hacia el sur hasta el cabo de Hornos.

\section{CORPUS FOTOGRÁFICO: CHAQUENSES Y FUEGUINOS BAJO EL LENTE}

Para nuestro análisis hemos tomado fotografías de algunos grupos originarios de Sudamérica que en un primer acercamiento, se hace evidente que comparten ciertas "marcas visuales" donde se inscribe la conformación de la otredad. Específicamente se puede observar un "modelo de lo bárbaro" constituido por la condición de desnudo de los retratados o una indumentaria muy precaria; en ocasiones, por la presencia de pintura corporal y por la exhibición de artefactos propios de la cultura a la que supuestamente pertenecen; por ejemplo, arco, flecha y adornos corporales como tocados, pulseras y collares. La mayoría de estas tomas está realizada en exterior, en medio de una naturaleza aparentemente no domesticada, pero con una estética propia del retrato de estudio de fines del siglo XIX (Fig. 1).

Desde el punto de vista del contexto de "lo fotografiado", estas imágenes constituyen universos visuales que podemos llamar regionales o territoriales, ya que aparecen representados varios grupos, los cuales generalmente no están reconocidos en sus diversidades étnicas. Por otra parte, también se observa una presencia común de ciertas entidades religiosas como los Salesianos, Franciscanos y Anglicanos. Sabido es que este trabajo misional significó muchos cambios en la vida y la cultura de estos grupos tan distantes en América, desde el tema aquí tratado muchas fotografías fueron obtenidas en el ámbito de las misiones donde los indígenas eran concentrados para vivir.

El primer grupo de imágenes con las cuales hemos trabajado está conformado por un conjunto de fotografías de la zona del Gran Chaco, donde aparecen lenguas, macás, sanapanás, angaités y chamacocos (del Chaco paraguayo), tobas (del Chaco argentino y paraguayo), mataco-wichí, mocovies, chulupíes y chorotes (del Chaco Argentino), y chiriguanos (del Chaco boliviano); estos grupos fueron ampliamente retratados por fotógrafos como Manuel de San Martín, Guido Boggiani (últimas décadas del siglo XIX), Otto Moessgen, Samuel Rimathé, Harry G. Olds, Theo Fumiére y miembros de la Sociedad Fotográfica Argentina de Aficionados (SFAA) (primera década del siglo XX), Alberto Ingimbert (ca. 1910), misioneros 

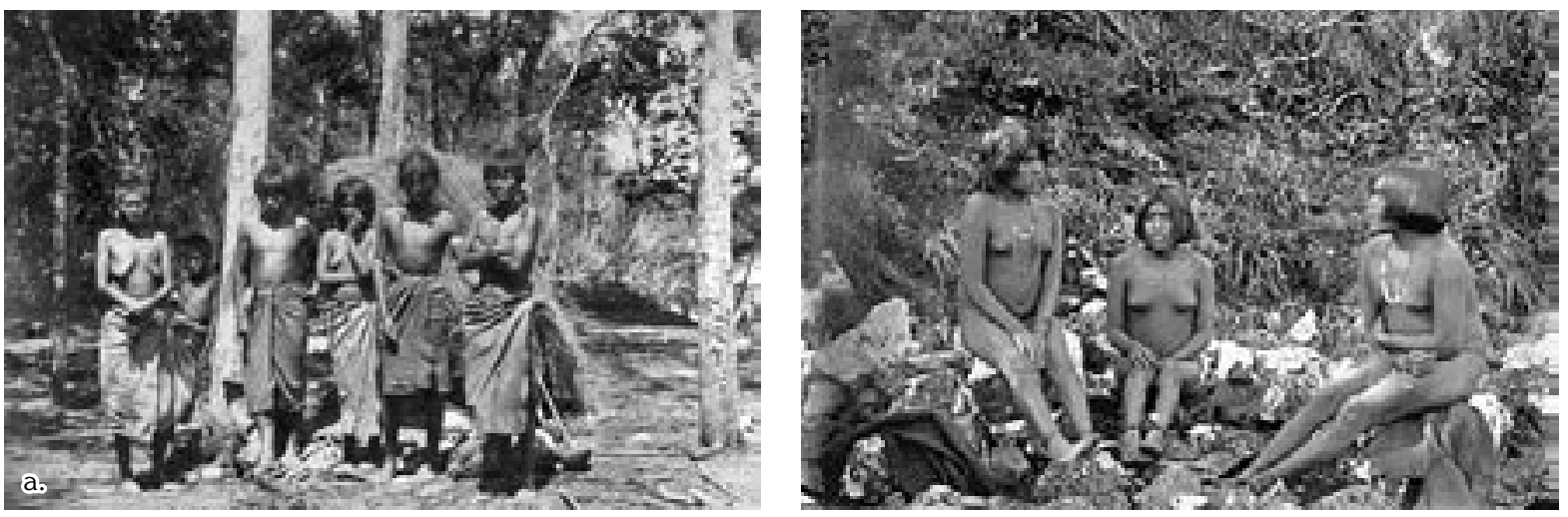

Fig. 1. a. Indios Lenguas: Fotografía de Manuel de San Martín. Álbum "Vistas del Paraguay”, (1879). Colección CEDODAL, Buenos Aires, Argentina, b. Grupo de mujeres Yagan. Archipiélago fueguino. Fotografía de Jean L. Doze y Edmond J.

A. Payen. Misión Científica al Cabo de Hornos (1882 - 1883). Photothèque du Musée de l'Homme, París, Francia.

franciscanos como Doroteo Gianecchini, Rafael Gobelli y Buenaventura Giulliani o anglicanos como Barbrooke Grubb y su staff (o encargos fotográficos que ellos realizaron entre 1907-1920 aproximadamente) y el fotógrafo alemán Hans Mann (1935-1937) ${ }^{5}$ (Fig. 2).

El segundo grupo, al otro extremo del continente lo constituyen fotografías de etnias de la Tierra del Fuego, como los Selk'nam, Yámana y Kawésqar (Odone y Mason 2003). Entre los ejemplos más notables debemos mencionar las tomas realizadas por los fotógrafos Jean - Louis Doze y Edmond - Joseph - Auguste Payen de la Misión Científica al Cabo de Hornos (1882 - 1883), expedición francesa que se llevó a cabo en la corbeta La Romanche; el explorador norteamericano Charles Wellington Furlong (1907 y 1908); el sacerdote y expedicionario italiano Alberto María De Agostini (cerca de 1910 a 1920) y el sacerdote y antropólogo austríaco Martín Gusinde (cerca de 1920 a 1930$)^{6}$ (Fig. 3).

Si bien las imágenes de estos autores están identificadas, debemos sumar a este corpus una gran cantidad de fotografías de las cuales se desconoce su autor pero que, debido a diversos antecedentes históricos y bibliográficos han podido ser ubicadas en su producción entre fines del siglo XIX y comienzos del XX. La identificación en archivo de imágenes fotográficas - ya sea his-

5 Para mayores antecedentes sobre el trabajo de estos fotógrafos se puede consultar Giordano 2004.

$6 \quad$ Para mayores antecedentes sobre el trabajo de estos fotógrafos se puede consultar Alvarado et al. 2007. tórica, contextual o cultural - actualmente implica transgredir el carácter de registro/documento de cualquier fotografía. Es justamente la problematización de ciertas adjudicaciones de pertenencias étnicas la que nos permite comprender cómo estas imágenes del Chaco y de Tierra del Fuego se han transformado en factores de configuración de ciertas identidades.

Así, hemos conformado un corpus de imágenes de muchos fotógrafos - conocidos y desconocidos - donde es posible reconocer ciertos dispositivos y procedimientos que operan en un determinado campo de la construcción cultural de lo visible. El "bárbaro" retratado en estos dos extremos del mundo americano comparte entonces ciertos elementos visuales básicos que hacen posible su identificación como "indígena"?

7 Esta reflexión es "nuestra", propia del analista de la imagen. Una lectura diferente de la confrontación objeto-objetivo podría surgir del abordaje que hagan las mismas comunidades, donde la producción-circulación se cerraría con la recepción: ¿será diferente lo que ven, cómo lo ven? ¿O ya habremos inculcado nuestros códigos de lectura, nuestros modos de leer, nuestro propio universo simbólico? Quedan, por ahora, como interrogantes. En tal sentido, se encuentra en sus inicios para el caso chaquense, un proyecto que sigue esta perspectiva de análisis, titulado "Captura por la cámara, devolución por la memoria. Imágenes fotográficas e identidad" (CONICET, PIP 6548, 2005-2007). Para el caso fueguino se encuentra en curso una experiencia de "antropología experimental", encabezada por la antropóloga María Paz Bajas, con entrevistas a indígenas de la zona de Puerto Edén, Región de Magallanes (proyecto FONDECYT 1030979). 

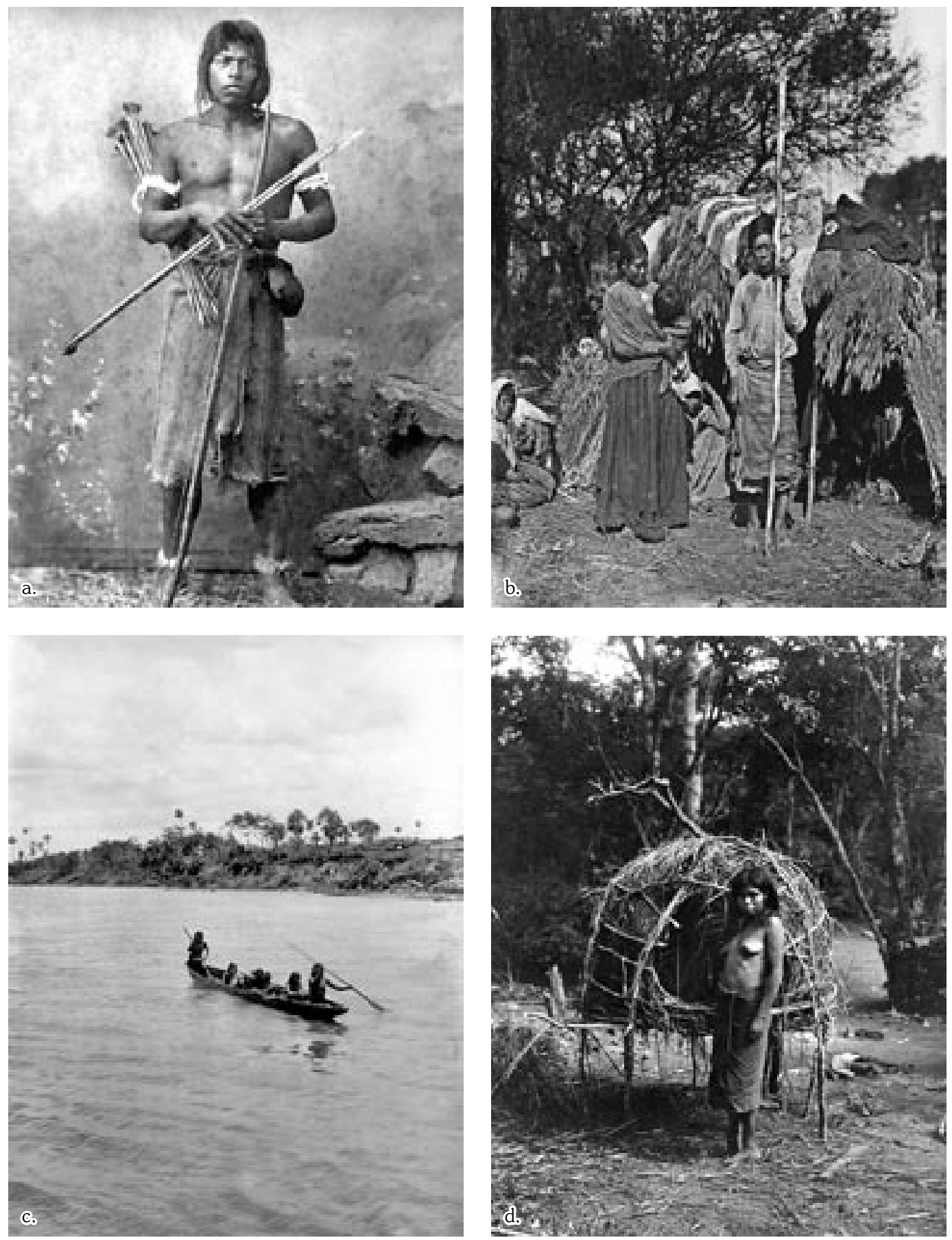

Fig. 2. a. Cacique Mataco. Chjaco Paraguayo. Fotografía de Manuel de San Martín (Ca. 1878) Colección Gotta, Buenos Aires. Argentina, b. "Canoa Lengua. Concepción". Fotografía de Guido Boggiani (1901). Museo de Ciencias Naturales de la Universidad de La Plata, La Plata, Argentina, c. "Toldo y familia Toba". Chaco Argentino Tarjeta Postal sobre una fotografía de Harry Grant Olds (1900) Colección CEDODAL, Buenos Aires, Argentina, d. "Joven Wichi". Chjaco Argentino, cerca del río Pilcomayo. Fotografía de Hans Mann (Ca. 1936). Archivo Fotográfico del Museo Etnográfico "Juan Bautista Ambrosetti", Buenos Aires, Argentina. 

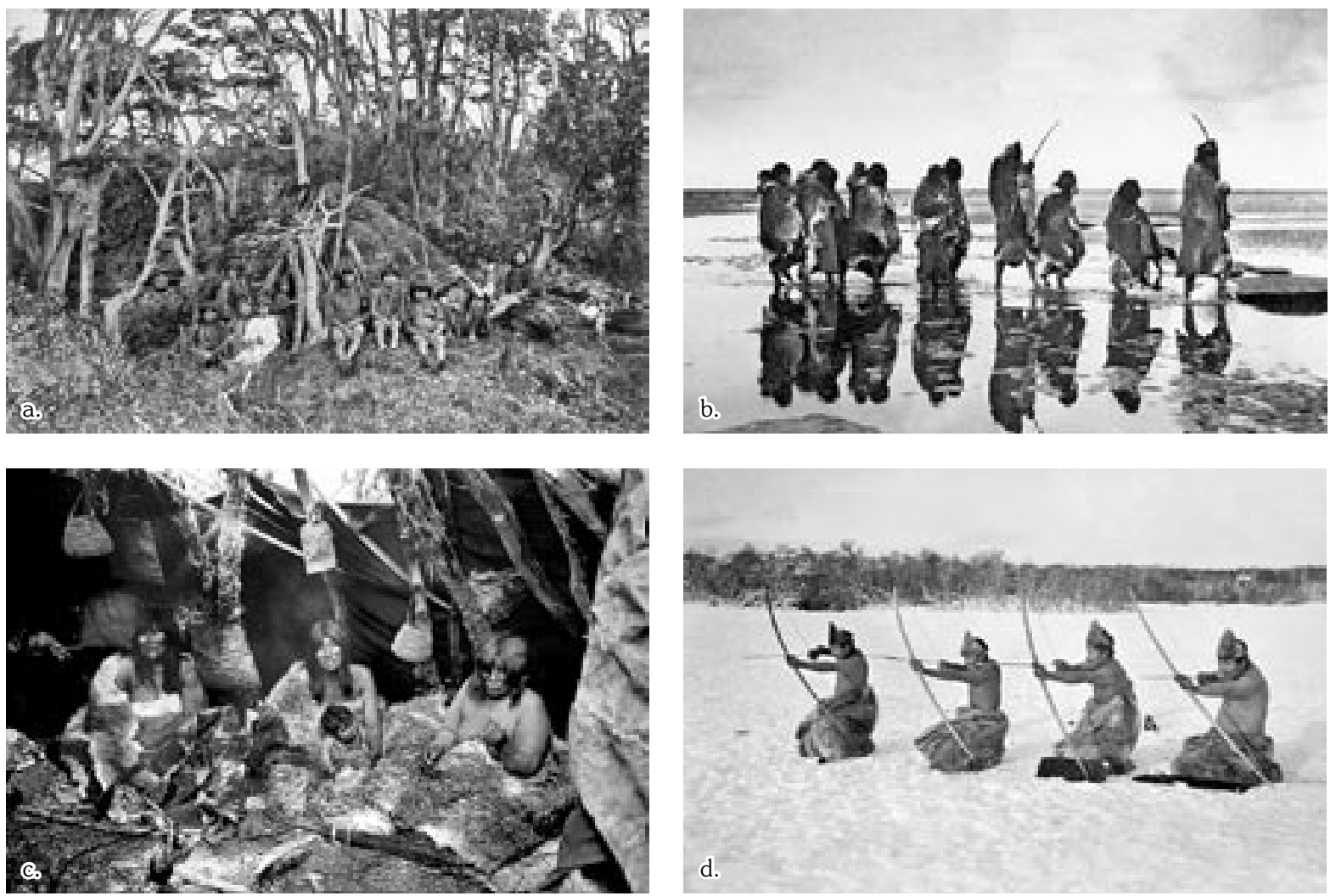

Fig. 3. a. De izquierda a derecha: Hombres: Panach, Eraloenysis, Ouaromayentsis, Tsingalai y un indígena no identificado. Mujeres: Oucilouchkoua Kipa, Mayachka Kipa, Taoualamyakou Kipa, Archipiélago fueguino, región del Cabo de Hornos. Fotografía de Jean L. Doze y Edmond J.A. Payen, Misión Científica al Cabo de Hornos (1882 - 1883), Photothèque du Musée de l'Homme, París, Francia, b. Grupo Selk'nam, costa Atlántica de la Isla Grande de Tierra del Fuego. Fotografía de Charles Wellington Furlong (1908). Dartmouth College Library,

Hanover, NH, USA, c. Mujeres y niños Selk'nam al interior de su vivienda. Isla Grande de Tierra del Fuego. Fotografía de Alberto María De Agostini (Ca. 1915). Museo Nazionale della Montagna, Torino, Italia, d. Arqueros Sel'knam en la estepa magallánica. Fotografía de Martín Gusinde (1923). Sankt Augustin, Alemania.

\section{CHAQUENSES Y FUEGUINOS BAJO LA MIRADA DE UNA "ECONOMÍA VISUAL"}

Si consideramos, por una parte, que la imagen fotográfica es un sistema convencionalizado de representación con sus respectivos códigos y dispositivos visuales y por otra, que la fotografía es un producto cultural, podemos plantear que en esta doble acepción de artefacto - imagen, puede ser sometida a un proceso de análisis e interpretación bajo la mirada de una "economía visual" que contemple aspectos tanto de su producción como de su circulación (Poole 1997). Se propone abordar la producción de las fotografías más allá de los individuos que las realizan, considerando más bien las estrategias de representación que están presentes en la imagen fotográfica, pero sin dejar de lado la relación que se establece en el acto fotográfico entre el operador (fotógrafo) y la cámara fotográfica (Flusser 1990). En cuanto a la circulación, se plantea indagar en los sistemas culturales y discursivos a través de los cuales las imágenes fotográficas se aprecian, se interpretan y se les asigna valor histórico, científico y estético.

Esta metodología de trabajo hace posible sistematizar y comprender procesos de construcción y montaje que están presentes en la representación de este "bárbaro" chaquense y fueguino, para así revelar los elementos históricos y estéticos que han participado en la conformación de las identidades étnicas (Alvarado y Mason 2001, Giordano 2003). 
PRODUCCIÓN: UNA CONSTRUCCIÓN VISUAL DEL "BÁRBARO" DEL CHACO Y DE TIERRA DEL FUEGO

Gran parte de los críticos formalistas ha planteado que la fotografía como sistema convencionalizado de representación tiene particularidades perfectamente reconocibles (Batchen 1997, Tagg 1988). De esta manera, consideramos que la fotografía presenta una naturaleza inherente, lo que implica procesos de producción específicos - fotográficos y tecnológicos - con sus respectivos dispositivos y procedimientos visuales que operan en un determinado campo de la construcción cultural de lo visible.

Como dispositivos, el encuadre, es decir los límites que establece el fotógrafo; el punto de cámara y de objetivo, que se relacionan con la posición y el enfoque; el plano y el ángulo de toma, que establecen una composición, por nombrar algunos, empapan lo fotografiado de un cierto tratamiento propio de lo fotográfico (Beceyro 2003).

Como procedimientos, los más frecuentemente utilizados por el fotógrafo son la "pose" y la "escena

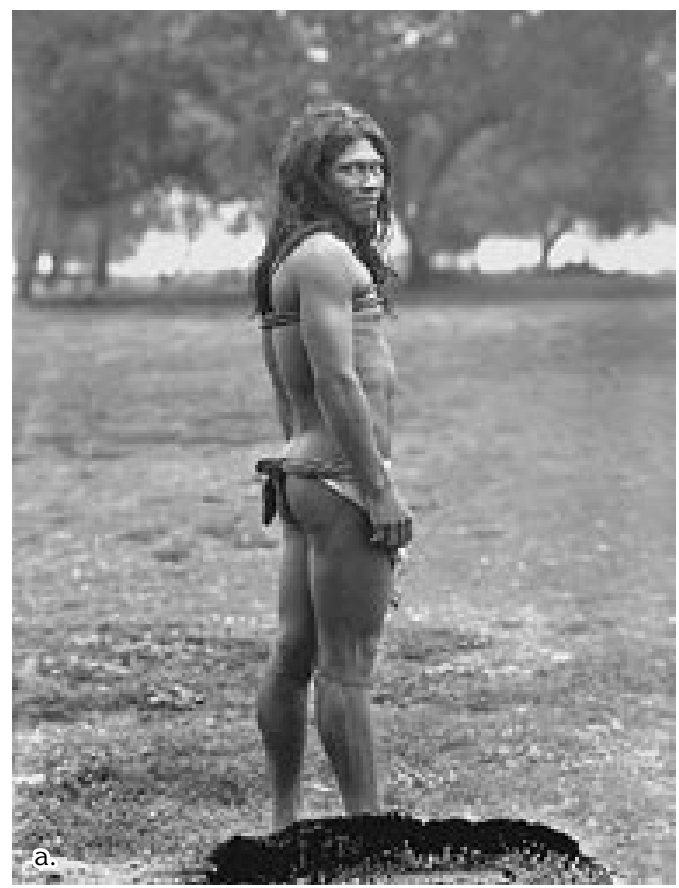

étnica", donde sujeto y objetos entran en una dinámica de relaciones espaciales, buscando muchas veces generar una atmósfera no contaminada por la presencia de la cámara (Alvarado et al. 2001). A través de estos procedimientos tan propios de lo fotográfico, la fotografía puede llegar a superar la simple reproducción de lo ya existente adquiriendo connotaciones que pueden escapar a su referente (Beceyro 2003; Soulages 2005).

En la fotografía de fines del siglo XIX y comienzos del XX, todo personaje fotografiado debía asumir frente a la cámara una pose obligada, no sólo por razones técnicas, sino también por las concepciones estéticas y compositivas de la época. Para el caso de los habitantes chaquenses o fueguinos, implicaba entonces que el retratado debía asumir una postura impuesta por el fotógrafo a su "modelo". Predominan las tomas frontales donde el retratado "posa" erguido mirando de frente a la cámara. La composición es austera con un encuadre cuidadosamente equilibrado y un ángulo de toma frontal, características que le otorgan a estas fotografías una estética severa, sin artilugios y que nos obliga a dirigir la mirada directamente sobre el retratado. El

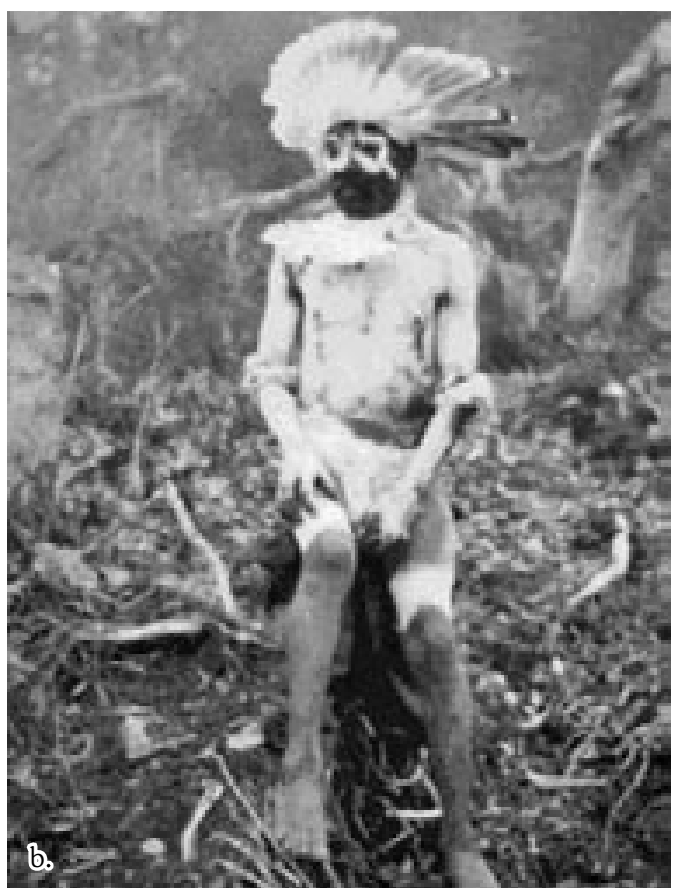

Fig. 4. Procedimiento visual: Pose. a. Ioata, indígena Chamacoco en la ciudad Puerto 14 de Mayo, Paraguay. Fotografía de Guido Boggiani. (1896 - 1901).Reproducida del texto "Guido Boggiani, fotógrafo". (Fri_y Fri_ova Editores, 1997), b. Kawésqar con pintura corporal Fotografía de Martín Gusinde (1923). Sankt Augustin, Alemania. 

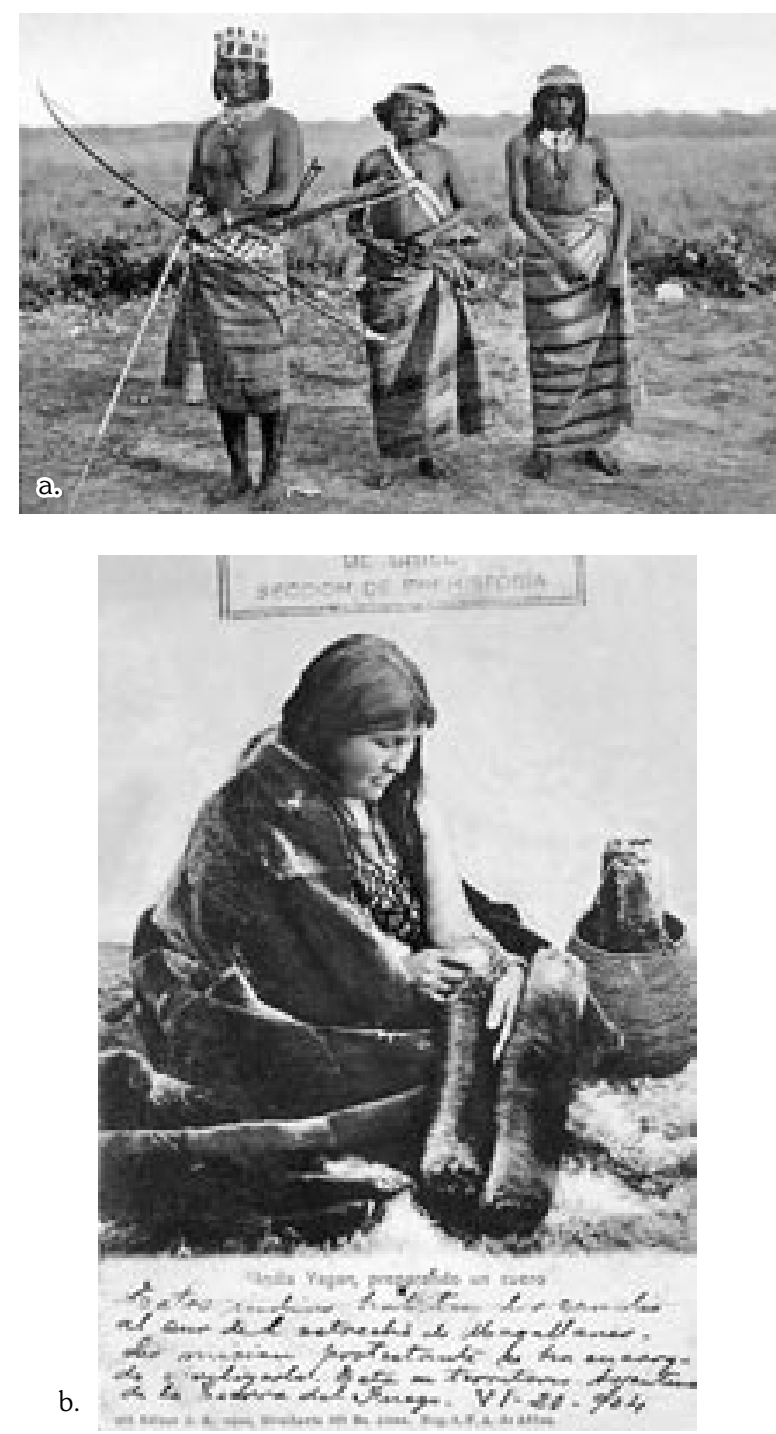

Fig. 5. Procedimiento visual: Pose. a. "Indios de la tribu Chamacocos". Chaco Paraguayo. Tarjeta Postal sobre una fotografía de autor desconocido. (ca. 1905). Colección Müller, Asunción, Paraguay, b. "India Yagan". Tarjeta Postal sobre una fotografía de autor desconocido, producida por el editor Roberto Rosauer, Buenos Aires, (Ca. 1904). Archivo Museo Histórico Nacional, Santiago.

procedimiento visual de la pose se enfoca a revelarnos la condición étnica del personaje, materializada en su indumentaria, más que en sus individualidades (Fig. 4). En otras producciones, si bien se conserva el encuadre y ángulo de toma, así como la indumentaria tradicional, hay cierto dramatismo materializado en una sutil mímica impuesta a los personajes. Como espectadores conferimos a estas fotografías una cierta espontaneidad, que nos revelaría un comportamiento que asumimos como propio de lo indígena, ignorando el montaje que ha realizado el fotógrafo a través de una cuidada gestualidad impuesta a través de una pose (Fig. 5).

También como procedimiento visual está la llamada "escena étnica". En muchas tomas hombres y mujeres parecen estar realizando parte de sus actividades cotidianas en medio de las cuales el fotógrafo, supuestamente, los ha sorprendido para fijarlos en una imagen. Si volvemos en una segunda mirada, podemos percatarnos sin mucho esfuerzo, que los gestos suspendidos, la parafernalia desplegada y la escenografía que enmarca la escena, han sido cuidadosamente dispuestos, para generar una atmósfera y una composición de carácter "étnico". El principio básico de este procedimiento visual lo constituye la delimitación de un espacio connotado como un fragmento de tiempo y lugar. En este verdadero acto teatral los dispositivos como el encuadre y los ángulos de toma siguen operando con la estética del retrato, donde, si bien los personajes están en el centro, la escenografía conformada por diferentes elementos - como árboles o viviendas - también constituye parte fundamental de la composición (Fig. 6).

De acuerdo a este análisis hemos podido percibir que el "salvaje" retratado en estos dos extremos del mundo americano comparte ciertas estéticas en su condición de "indígena". Así, las peculiaridades que presentan estos retratos, no radican tanto en la temática étnica a la que aluden, sino en la estética singular que exhibe la composición fotográfica, resultado de la disposición de personajes y parafernalia sobre ciertos escenarios. En estas composiciones cuidadosamente montadas, los sujetos directamente enfrentados al lente nos refractan un indígena cuya desnudez, adornos y artefactos culturales se transforman en los referentes fundamentales de su identidad étnica. Desde el punto de vista de la producción, la construcción visual del chaquense y el fueguino se torna eficiente e indiscutible.

\section{CIRCULACIÓN: DE VIAJE POR \\ SUDAMÉRICA, LOS CHAQUENSES QUE VISITARON LA TIERRA DEL FUEGO}

Producidas las fotografías bajo las condiciones descritas y analizadas, éstas inmediatamente 

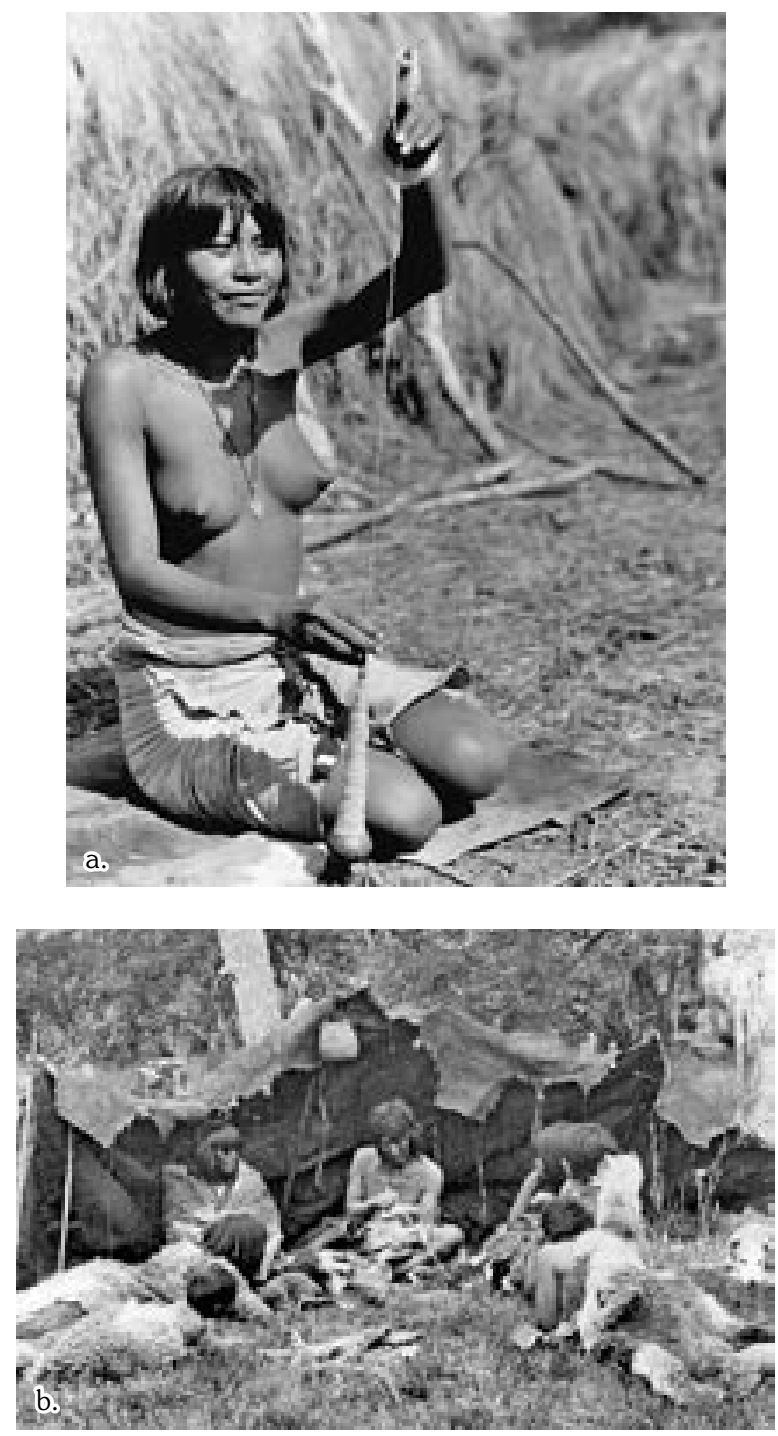

Fig. 6. Procedimientos visual: Escena étnica. a. Mujer chulupí hilando con uso. Chaco Paraguayo. Fotografía de autor desconocido (Ca. 1935). Museo Antropológico

"Andrés Barbero", Asunción Paraguay, b. El cazador Selk'nam Najmishk fabricando una flecha en las cercanías de río Fuego, Isla Grande, Tierra del Fuego. Fotografía de Charles Wellington Furlong (1908).

Dartmouth College Library, Hanover, NH, USA.

comenzaron a ser reproducidas en variados sistemas culturales y discursivos, siendo sometidas a verdaderos procesos de apropiación en los diferentes contextos iconográficos en que iban siendo actualizadas. Es en el marco de esta "apropiación", que surge de políticas de representación, pero también de los modos de construcción de la alteridad, que muchas de las imágenes de nuestro corpus asumen un interés sobresaliente (Giordano 2004). Publicadas en diversos contextos iconográficos como textos de historia y antropología, folletos de turismo, campañas publicitarias, por nombrar algunos, pueden ser leídas desde un interés que va mucho más allá de lo documentalista, asumiendo también una función a veces exotizante, en tanto muestran lo extraño y desconocido. Así, estas imágenes tuvieron una vida muy diferente al contexto iconográfico en que su productor como fotógrafo las presentó originalmente.

Bajo esta perspectiva, analizaremos en particular, dos fotografías que presentan una sobreexhibición y una trayectoria de "trashumancia iconográfica" formidable y que casi como un ejemplo paradigmático, nos permiten comprobar las influencias que han ejercido en la construcción visual de ciertas identidades étnicas.

La primera de éstas corresponde a una toma en formato horizontal de un grupo de diez sujetos posando frente a una empalizada de madera que parece formar parte de la construcción de una vivienda. Desde el punto de vista de los dispositivos visuales fotográfico, las cuatro mujeres semi agachadas al centro y los seis hombres de pie atrás, posan encuadrados por un lente frontal, que los sitúa al centro de una equilibrada composición. Visten una prenda de género de la cintura hacia abajo y algunos de los varones exhiben arcos y flechas. Desde el punto de vista de los procedimientos visuales, por la distribución de los sujetos, se hace evidente que el fotógrafo ha buscado hacer un retrato de estos personajes ataviados con sus propias ropas $y$ artefactos.

Si revisamos la circulación de esta fotografía de acuerdo a una metodología propia de una "arqueología de la imagen" podemos distinguir e individualizar diversos estratos visuales o contextos iconográficos con sus respectivos referentes históricos y sociales (Edwards 1992). Así, se pueden establecer parte de los sistemas culturales y discursivos en donde esta imagen ha sido actualizada y abordar las significaciones que ha adquirido. De esta manera vemos cómo esta fotografía va sufriendo ciertos procesos de apropiación que la connotan de diferentes valores al ser apreciada e interpretada, de acuerdo a las características visuales de los individuos allí fotografiados. 

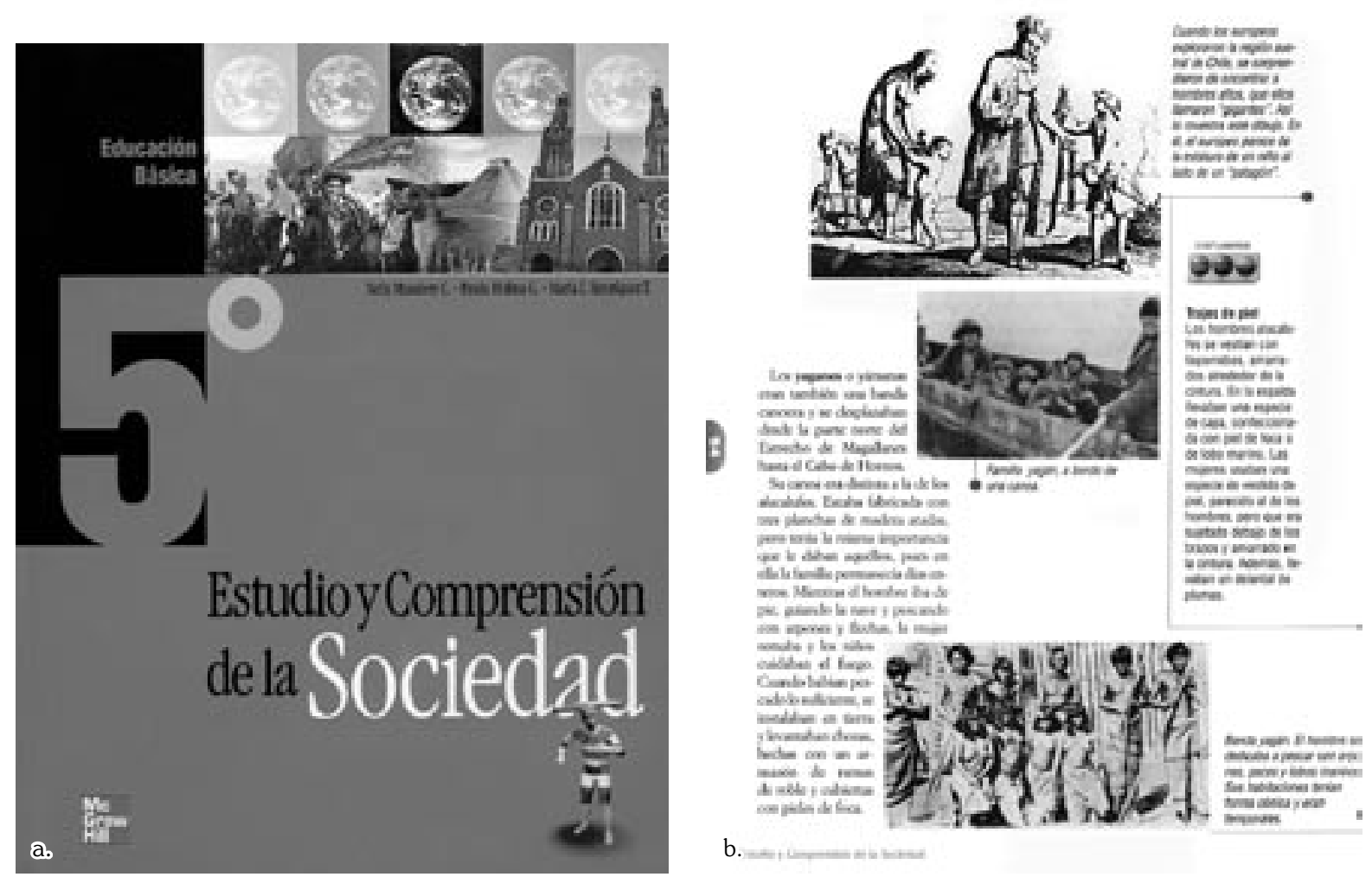

Fig. 7. Estrato A. a. Portada texto Estudio y Comprensión de la Sociedad, 5to. Educación Básica. Nelly Musalem, Paula Molina y María Enríquez. Editorial Mc Graw Hill, Santiago, Chile, 2002, b. Página 54 del texto.

Analicemos algunos de estos estratos visuales realizando un recorrido arqueológico visual, del presente hacia el pasado, para conocer los diferentes contextos iconográficos donde ha circulado.

ESTRATO A: El primer estrato de publicación de que encontramos esta fotografía es un texto del Ministerio de Educación de Chile para 5to. Año Básico, titulado Estudio y Comprensión de la Sociedad de los autores Nelly Musalem, Paula Molina y María Enríquez, impreso en Santiago el año 2002, para ser repartido a los educandos de todo el país. En la página 54 aparecen tres imágenes con relación a los indígenas fueguinos, la última de ellas corresponde a nuestra fotografía. La etiqueta que la acompaña dice: Banda Yagán. El hombre se dedicaba a pescar con arpones peces y lobos marinos. Sus habitaciones tenían forma cónica $y$ eran temporales. Evidentemente, considerando que el texto está destinado para que los niños de 7 a 9 años adquieran conceptos que les permitan posicionarse como individuos que forman parte de una sociedad pluri étnica, los autores buscan ilustrar con esta fotografía un modo de vida y una cultura de un grupo fueguino específico: los Yagan (Fig. 7).

ESTRATO B: El segundo estrato iconográfico donde aparece esta fotografía -también del 2002-corresponde a la imagen № 2 de un CD titulado "Tribute to the Patagonic Ethnic Spirit. Photo Album with 100 pictures". Producido y publicado por Millennium Computación en la ciudad de Punta Arenas. No hay datos que permitan situarla en un contexto histórico específico, ya que no aparece ni año ni autor de la toma. Sólo figura como parte de un conjunto iconográfico cerrado, presentado como "Álbum", donde se rinde un tributo a los pueblos originarios de la zona del extremo sur de América. El texto en inglés que la acompaña hace alusión a la naturaleza como forjadora de un sujeto, situando al hombre en un momento de la era "paleolítica", donde el mundo conserva su estado primigenio (Fig. 8). 

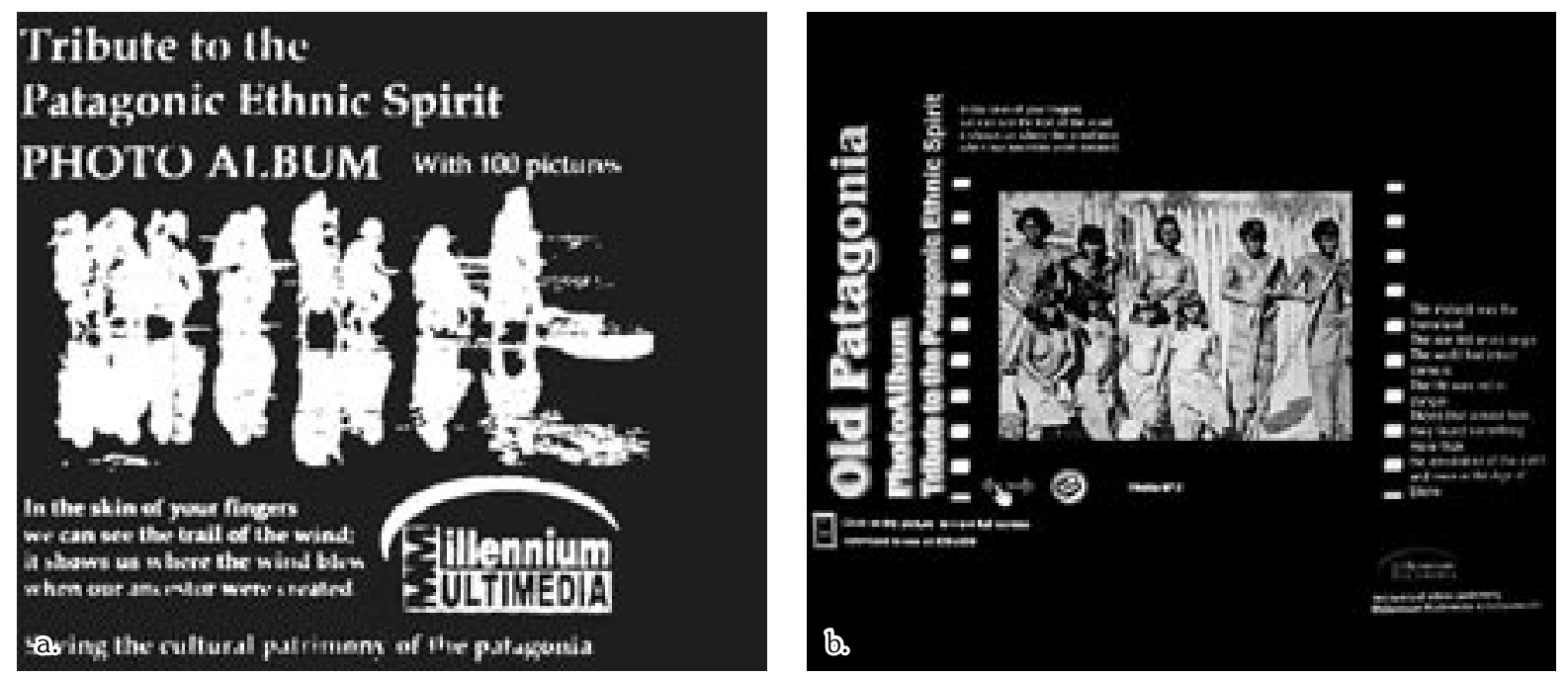

Fig. 8. Estrato B. a. Portada de CD titulado Tribute to the Patagonic Ethnic Spirit. Photo Album with 100 pictures. Punta Arenas, Chile, 2002, b. Imagen № 2 de este CD.

The instincts were the homeland.

The rain fell on its origin.

The world had intact corners.

The life was not in danger

Those that arrived her, they found something more than desolation of the earth and men in the Age of stone

Esta publicación se presenta como un conjunto de imágenes "étnicas" donde destaca el desnudo como parte de una estética que exalta lo primigenio y lo ancestral. Al contrario del ejemplo anterior, donde se atribuía a los fotografiados una pertenencia a la etnia de los Yámana, en este caso se les adjudica identidad étnica genérica a los pueblos originarios del extremo sur. Así, se instala visualmente un sujeto ahistórico, habitante arcano y anónimo de un mundo ya extinto.

ESTRATO C: En tercer lugar esta imagen la encontramos reproducida dos veces en el texto Impresiones de la República de Chile en el Siglo XX. Historia, gente, comercio, industria, dirigido por Reginal Lloyd con la colaboración de los editores W. Feldwick, L. T. Delaney y José Plá Cárceles, impreso en Londres en 1915. En el capítulo Población e Inmigración, en la página 107, aparece en medio de cinco fotografías dispuestas bajo el título Tipos de indios habitantes del extremo austral. 1, 2, 3 Patagones, 4 y 5 de Tierra del Fuego. La acompaña un retrato de cinco mujeres de pie, que corresponde justamente al otro caso que analizaremos más adelante. Posteriormente, en la página 555, en el capítulo titulado Los Indios, esta imagen aparece inserta en medio del texto en que se dice: En la Tierra del Fuego é islas adyacentes viven tres razas indias: los yaganos, los alacalufos y los onas. Estos aborígenes cuya inteligencia es ínfima, son designados con el nombre de fueguinos. $\mathrm{Su}$ etiqueta reafirma esta idea: Naturales de Tierra del Fuego. En este estrato la imagen se sitúa en un contexto iconográfico casi 100 años más antiguo que el estrato $\mathrm{B}$, como parte de un texto que tiene como objetivo entregar un completo panorama de Chile de su historia y situación como naciente república americana. Las etiquetas de las imágenes entregan un certificado indesmentible acerca de la pertenencia étnica de los fotografiados, pero, también como en el estrato anterior, no se especifica un grupo específico. Es evidente que estas fotografías están siendo utilizadas como ilustraciones de un discurso social y político, donde las imágenes de los fueguinos y de otros pueblos indígenas que aparecen entre mezclados con el texto, se constituyen en referentes de una realidad "país" (Fig. 9).

ESTRATO D: Un cuarto estrato donde aparece esta imagen lo constituye la publicación del poema La Araucana de Alonso de Ercilla y Zúñiga editado en 1910 en Santiago con motivo del centenario de 

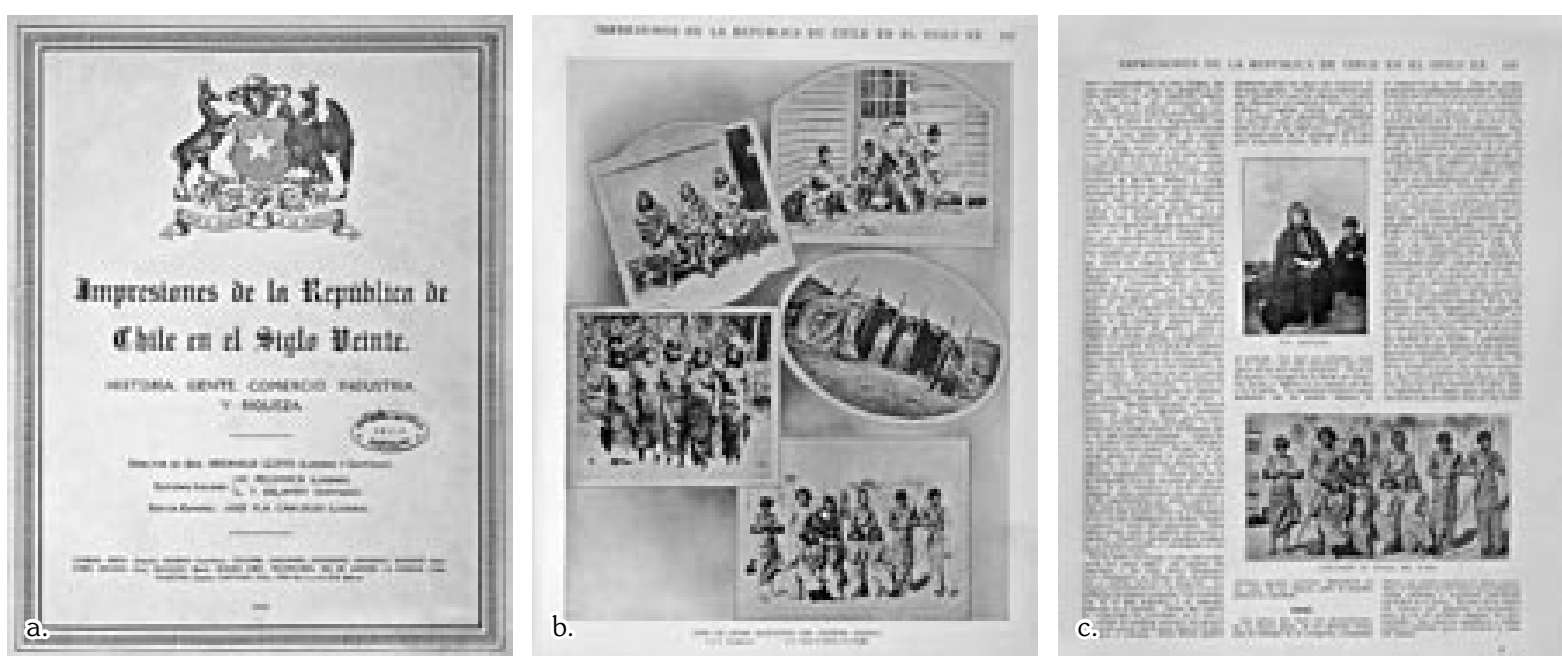

Fig. 9. Estrato C. a. Portada texto Impresiones de la Republica de Chile en el Siglo XX. Historia, gente, comercio, industria (Lloyd, 1915), b. Página № 107 del texto, c. Página № 555 del texto.

la independencia de Chile, por José Toribio Medina y la Imprenta Elzeviriana. Tal como se señala en su portada la edición fue ilustrada con grabados, documentos, notas históricas y bibliográficas y una biografía del autor. La fotografía que analizamos aparece encabezando el Canto XXXI, en donde Cuenta Andresito a Reinoso lo que con Pran dejaba concertado. Habla con Caupolicán cautelosamente, el cual engañado, viene sobre el fuerte, pensando hallar a los españoles durmiendo. Todos los cantos de este poema épico están encabezados por una imagen fotográfica caprichosamente recortada con el fin de producir un efecto compositivo en la diagramación. Si leemos con atención el encabezamiento así como el texto de este canto, se hace evidente la imposibilidad de establecer una relación directa entre el contenido del poema y la imagen impresa. Veamos como ejemplo la primera estrofa:

"La más fea maldad y condenada.

Que más ofende a la bondad divina.

Es la traición sobre amistad forjada.

Que al cielo, tierra y el infierno indina:

Que aunque el señor de la traición se agrada.

Quiere mal al traidor y le abomina;

¡Tal es el nefario maleficio,

Que indigna al que recibe el beneficio!"
De esta manera, la imagen fotográfica, utilizada ahora en un contexto iconográfico relacionado más bien con lo literario y la creación artística, pareciera buscar la representación de un sujeto asociado a las luchas que comprometieron a hispanos y mapuche en los primeros años de la conquista. Si bien las imágenes que encabezan los textos presentan etiquetas de referencias, se puede percibir por la vestimenta y joyas que la mayoría de las fotografías reproducidas corresponde a retratos $y$ escenas tomadas al mundo mapuche a fines del siglo XIX y comienzos del XX ${ }^{8}$. En este sentido, se hace evidente las diferencias visuales con la imagen de los indígenas que encabeza el canto XXXI. Así, esta fotografía parece estar siendo utilizada en la medida que presenta un sujeto cultural y visualmente diferente y exótico cumpliendo con representar al indígena valiente y aguerrido, detalladamente descrito por Ercilla. No se busca una sintonía histórica entre el sujeto fotografiado y el texto, se busca una sintonía étnica - visual (Fig. 10).

ESTRATO E: En cuarto lugar están los álbumes fotográficos de comienzos del siglo XX. Estos se

8 Estas fotografías se encuentran ampliamente identificadas tanto en sus autorías como en fechas, lugares y personajes retratados en el texto "Mapuche. Fotografías siglo XIX y XX. Construcción y montaje de una imaginario" (Alvarado, Mege y Báez; 2001a). 

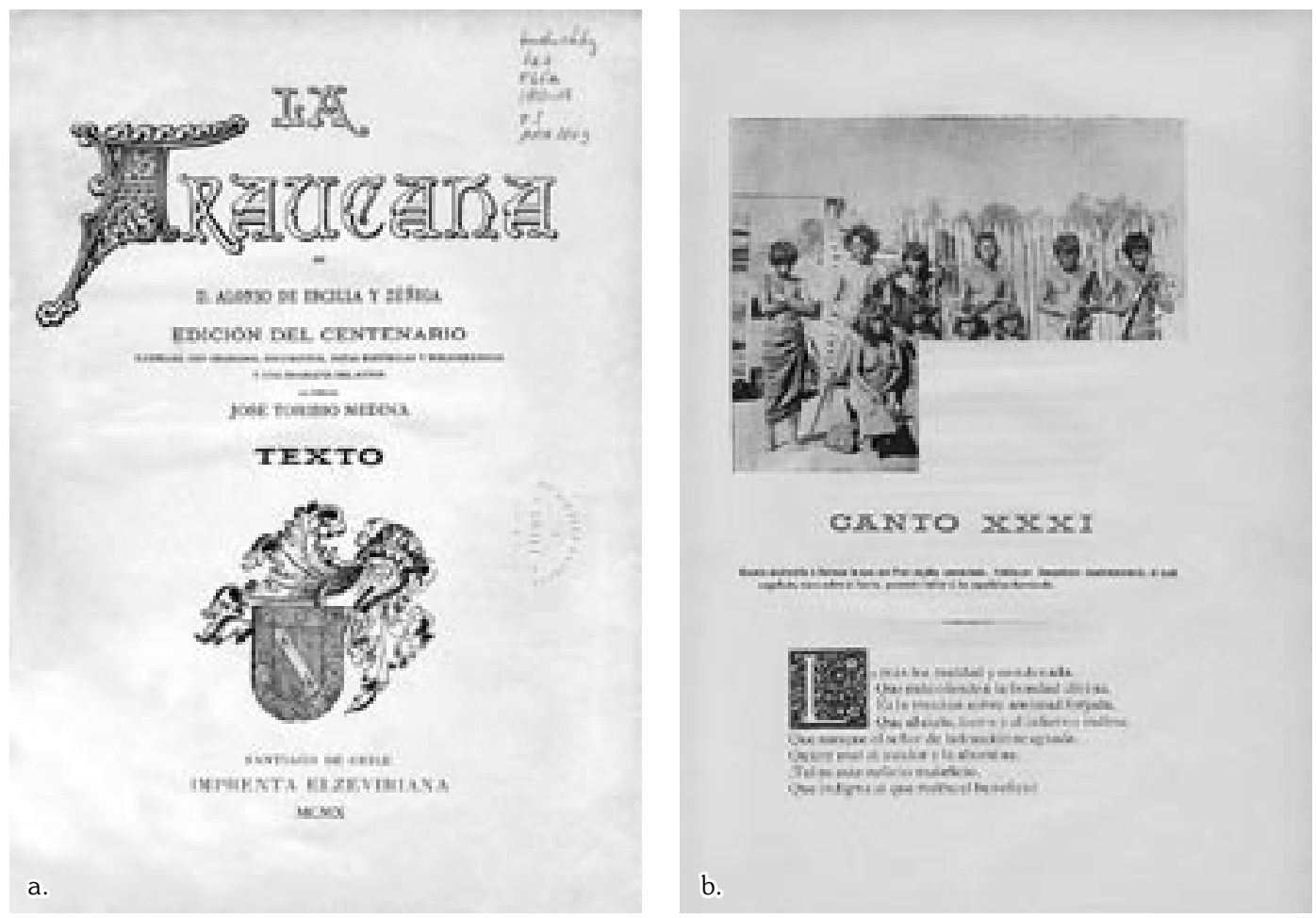

Fig. 10. Estrato D. a. Portada del poema La Araucana de D: Alonso de Ercilla y Zúñiga, (Medina, 1910), b. Página del canto XXXI.

caracterizan porque son impresos, por lo tanto, las imágenes no presentan soporte en papel emulsionado. Este tipo de álbum fue de amplia producción a comienzos del siglo XX en Santiago y otras ciudades de Chile. Eran publicaciones impresas que permitían una gran difusión de material fotográfico, siendo muchos de ellos conformados por pequeños cuadernillos -a veces llamados Entregas- que aparecían periódicamente y podían adquirirse por separado. Generalmente, las fotografías que contenían estaban ordenadas para dar una visión miscelánea de Chile, sus paisajes, ciudades, monumentos y avances industriales. En otras ocasiones una Entrega podía tener una temática específica. Populares eran los cuadernillos dedicados a Valparaíso, la travesía de la cordillera de los Andes por el paso de Uspallata, o los baños termales de la zona central de Chile. Cada imagen era publicada a página completa, acompañada de un texto explicativo que entregaba al lector información de interés general.

La fotografía que nos interesa aparece en el Álbum Panorama de Chile y Álbum Vistas de Chile ambos, impresos en Santiago por Litografía
Leblanc, alrededor del año de 1910. En el primer Álbum mencionado, en la Entrega № 21 aparece acompañada de un texto que resulta bastante significativo:

La población indígena de la Tierra del Fuego, se divide en tres clase a saber: Tequiniques ò Yaganes, que habitan la región entre el canal de Beagle i el Cabo de Hornos, Alicaluf en la costa oxidental i parte del Estrecho de Magallanes $i$ Onas o Yacanes i también Yacanacunis siendo esta última la más fuerte y numerosa, pues ocupa toda la parte occidental de la Isla Grande. Son gentes esbeltas, de estatura muy desarrollada, valientes y ágiles, viven de la caza del huanaco i usan sus pieles como vestido. No forman tribu i son vagabundos por instinto y por necesidad.

En este caso se persigue una correspondencia del texto y la imagen con una etiqueta que informa ampliamente acerca de la población fueguina, su territorio y sus costumbres, aunque nuevamente no se les adscribe una etnia específica a los personajes 

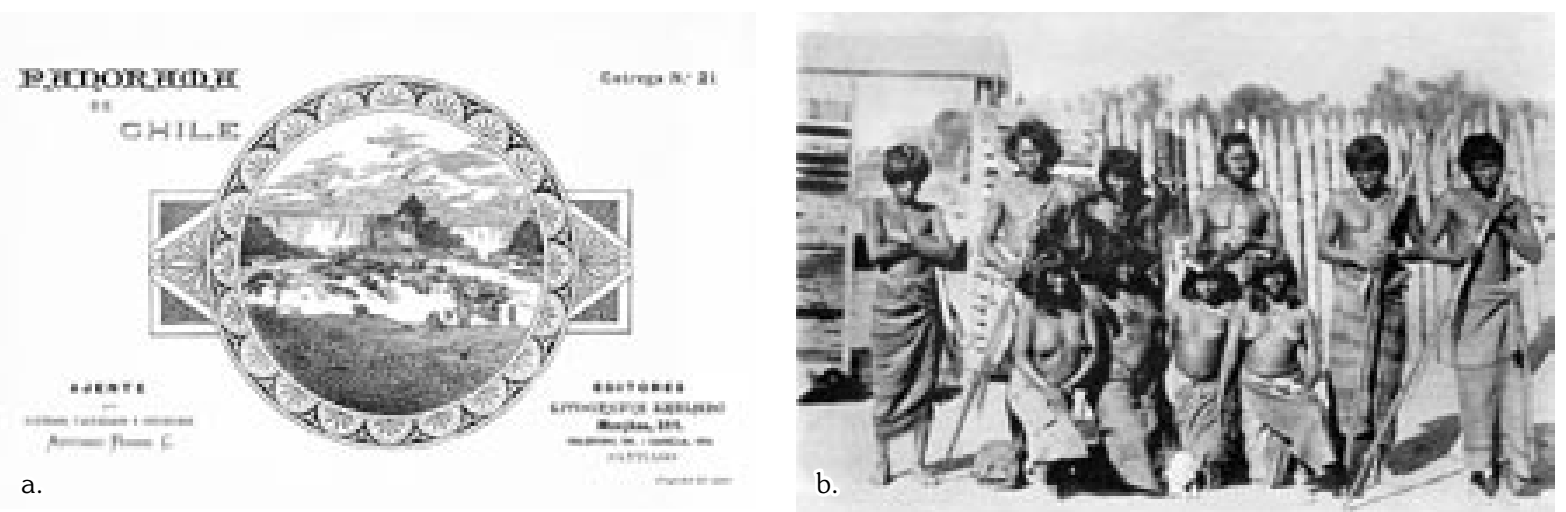

Fig. 11. Estrato E. a. Portada Álbum Panorama de Chile, Entrega № 2, Litografía LeBlanc, Santiago, Chile. Ca. 1910 , b. Pagina sin número del Álbum.

retratados. La correspondencia visual-étnica se torna indesmentible para cualquier espectador (Fig. 11).

ESTRATO F: Por último, un quinto estrato es el artículo La geografía de Tierra del Fuego y noticias de la antropología y etnografía de sus habitantes de Alejandro Cañas Pinochet, publicado como parte de los Trabajos de la III Sección de Ciencias Naturales, Antropológicas y Etnológicas. Tomo I, editados bajo la dirección del Prof. Carlos E. Porter. Volumen XI de los Trabajos del Cuarto Congreso Científico (1은 Pan Americano) celebrado en Santiago de Chile del 25 de diciembre de 1908 al 5 de Enero de 1909. Imprenta, litografía y Encuadernación "Barcelona", 1911. Nuestra imagen aparece entre las página 36 y 37, acompañada de la etiqueta Foto Grupo de Indios Ona: hombres y mujeres y forma parte de un conjunto de retratos y fotografías desplegadas a los largo del artículo, con el fin evidente de generar un corpus que persigue dar cuenta del territorio y la población de Tierra del Fuego en un contexto académico y científico (Fig. 12).

$Y$ esto nos lleva al segundo caso que deseamos analizar, ya que en el corpus de fotografías de este mismo artículo de Cañas Pinochet (1911), aparece también entre las páginas 36 y 37, la imagen de un grupo de cinco mujeres todas de pie desnudas de la cintura hacia arriba. Desde los dispositivos visuales el encuadre está dominado por la presencia de las fotografiadas. Desde los procedimientos visuales, las retratadas posan, enmarcadas por una abundante vegetación conformada por árboles de gruesos troncos y tupido ramaje, llenando casi completamente la composición. La etiqueta que acompaña la imagen dice Grupo de mujeres onas (Fig. 13). Como ya veíamos con anterioridad, esta imagen también aparece en el estrato C, acompañada de la etiqueta Onas de Tierra del Fuego (Fig. 9b).

Si continuamos con nuestra práctica de excavación arqueológica-visual en otros contextos iconográficos, rápidamente nos damos cuenta como estas dos imágenes, que documentan un sujeto extraño y desconocido etiquetado como ona, o más propiamente como fueguino, están muy lejos del su contexto iconográfico de origen.

Volviendo al presente, en un estrato visual que podemos clasificar de actual, encontramos en las páginas 52 y 53 del catálogo titulado Fotografía Latinoamericana. Colección CEDODAL publicado en el año 2001 en Buenos Aires, la fotografía descrita anteriormente como Grupo de mujeres onas, pero ahora acompañada de otra información totalmente distinta (Fig. 14) ${ }^{9}$. Para la imagen denominada con el № 41 se individualiza su autor como Manuel de San Martín, el lugar como Paraguay y la fecha se sitúa cerca de 1890, también se identifica la técnica como "copia de albúmina" y el tamaño, 14 x 20 $\mathrm{cm} .{ }^{10}$. Ahora, lo más interesante, es la etiqueta que individualiza a las mujeres retratadas como Indígenas de la tribu Angaites y el texto que la comenta:

9 La fotografía que acompaña la imagen de San Martín, etiqueta como Devotos de Salta pertenece al fotógrafo Arturo Word Boote y está fechada cerca de 1885.

10 Nótese que al costado de la primera mujer de la izquierda, bajo su mano, se aprecia una mancha negra. No sabemos su origen, probablemente se deba a una pérdida de la emulsión, pero esta particularidad ha permitido identificar que se trata siempre de la misma imagen reproducida en distintos contextos iconográficos. 


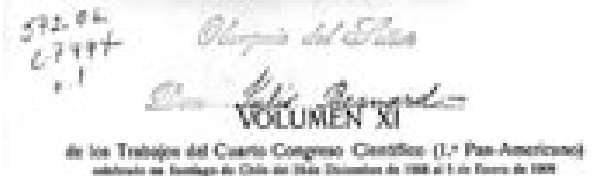

TRasyos de La a secoow

\section{Ciencias Naturales, Antropológicas y Etnológicas}
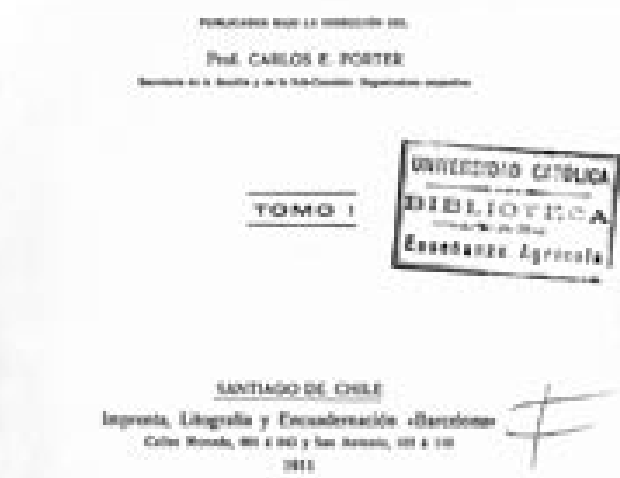

a.

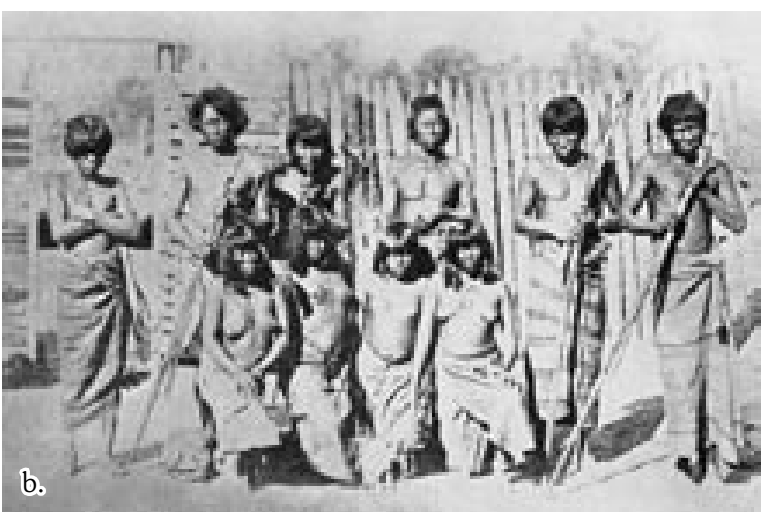

Fig. 12. Estrato F. a. Portada texto Trabajos III Sección de Ciencias Naturales, Antropológicas y Etnológicas, Tomo I (Cañas, 1911), b. Imagen entre las páginas № 36 y № 37 del texto.

Esta fotografía de un conjunto de mujeres de la tribu angaites en la selva paraguaya alcanzó singular fortuna ya que fue reproducida en postales por su autor Manuel San Martín en el Paraguay pero también lo sería, sin dar precisiones de autoría y variando la procedencia tribal, por parte del fotógrafo Ingimbert en Corrientes que la editó como postal una década más tarde. El grupo

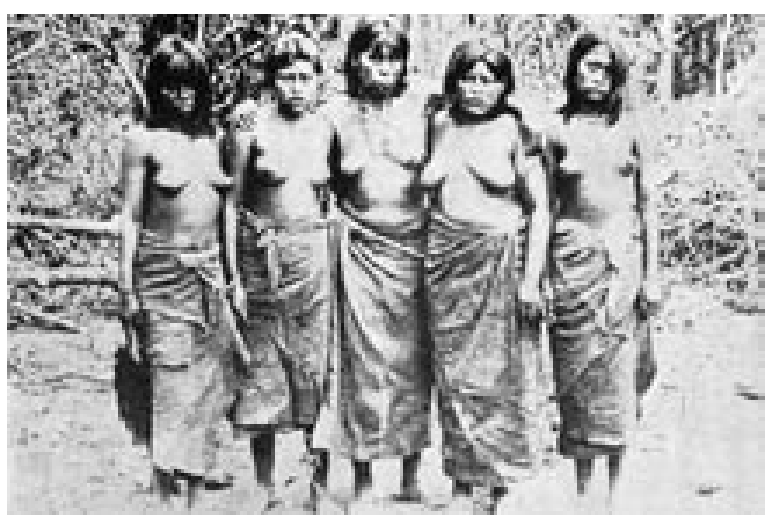

Fig. 13. Imagen entre las páginas № 36 y № 37 del texto de Alejandro Cañas Pinochet (1911).

femenino muestra la marginalidad de estas etnias paraguayas que ha perdurado durante buena parte del siglo $X X$.

Este comentario nos impulsa a continuar buscando otros sedimentos visuales para indagar en que contextos iconográficos aparece esta imagen y acompañada de que información. De este modo, en un sedimento visual de comienzos de la décadas de 1900, tal como se mencionaba en el catálogo de CEDODAL, la encontramos en formato de Tarjeta Postal, publicada por el fotógrafo e impresor Alberto Ingimbert en la ciudad de Corrientes (Argentina), pero con una etiqueta en que señala Grupo de indias tobas, otorgándole un filiación étnica diferente, pero siempre en la zona del Chaco (Fig. 15). Una década después, encontramos esta misma fotografía -también en un formato de Tarjeta Postal- publicada por el editor Guillermo de Grüter, en la ciudad de Asunción, cerca del año de 1910, en la Serie Lenguas (Brasil, Bolivia, Argentina, Paraguay, etc.). En este caso la filiación étnica se desplaza a los Lenguas y se amplia a varias repúblicas americanas (Fig. 16).

Por último, uno de los registros más tempranos que tenemos de esta imagen corresponde al momento en que probablemente fue producida como fotografía, ya que aparece en un Álbum titulado Vistas del Paraguay editado en Asunción en el año 1878 por el fotógrafo Manuel San Martín, con la etiqueta Indígenas de la tribu Angaites (Fig. 17). Este fotógrafo español como importante documentalista de vistas urbanas, escenarios naturales y grupos originarios en el Paraguay, fue uno de los primeros que en las décadas de 1870 y 1880 se 

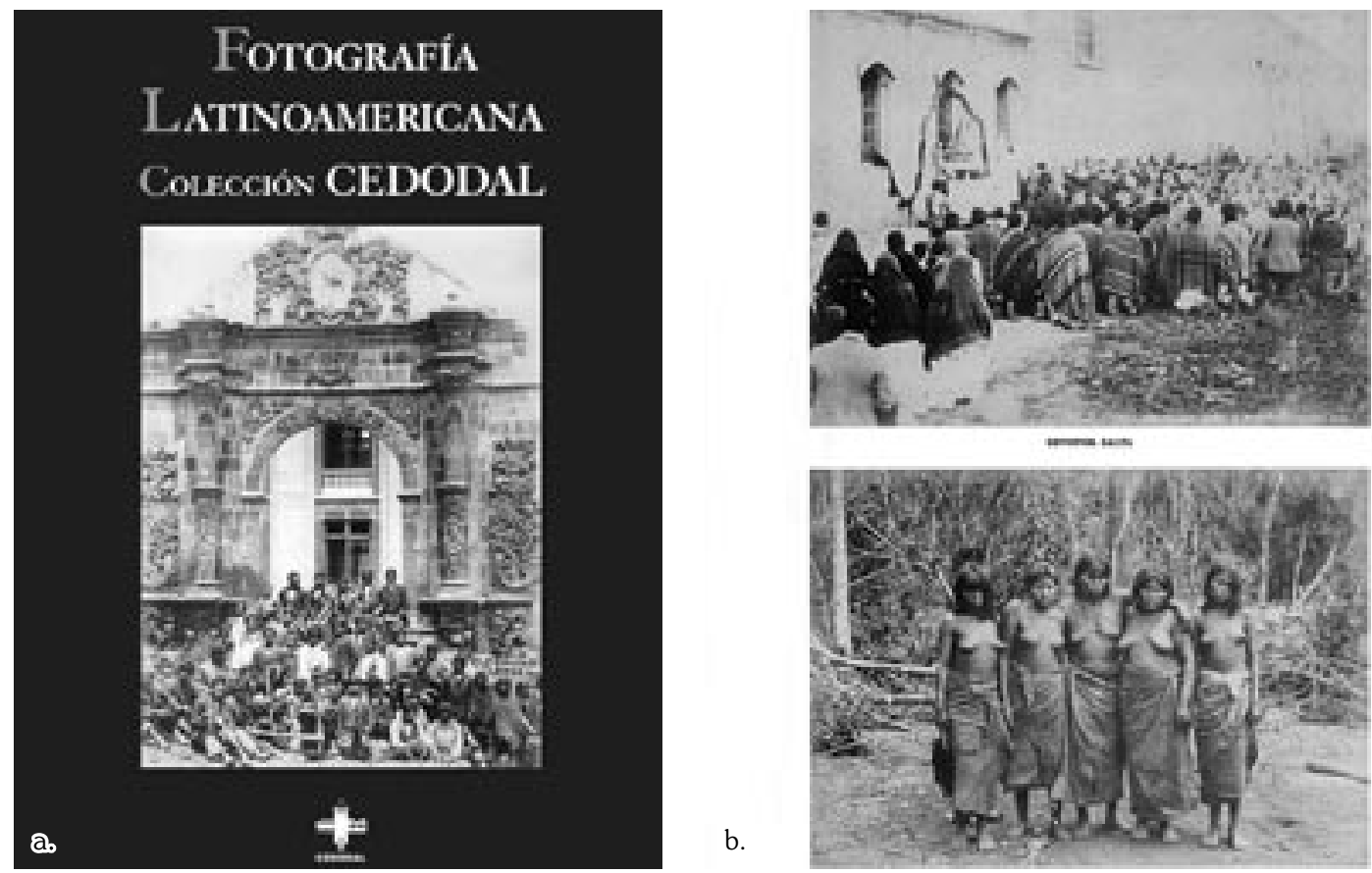

Fig. 14. a. Portada Catálogo Fotografía Latinoamericana. Colección CEDODAL, Buenos Aires, Argentina, 2001, b. Página № 53 del Catálogo.

internó en la región chaqueña para retratar a los indígenas en su ambiente natural, aunque también les tomó varias imágenes en estudio. Gran parte de esta producción visual tuvo una amplia difusión a fines del siglo XIX y principios del XX, y algunas de sus tomas aún siguen circulando profusamente, como lo demuestra el recorrido que hemos realizado. El hallazgo de este último estrato en el fondo de nuestra excavación visual ha permitido no sólo encontrar el autor de una de estas fotografías que analizamos, sino también dilucidar una pertenencia étnica específica de los sujetos fotografiados. Más allá de la legitimidad que podemos otorgarle a la etiquetación que hace San Martín como indígenas de la tribu angaites, más que sorprendernos por la verdadera aparición de esta nueva identidad, lo realmente importante es que esta filiación posiciona esta imagen fotográfica en una pertenencia étnica muy lejana del mundo de los llamados onas, habitantes de Tierra del Fuego. Ahora, si bajo un zoom fotográfico nos acercamos a los rostros de los personajes fotografiados y observamos cuidadosamente a cada una de las retratadas, surgen otras individualizaciones que nos llevan a fijar otras identidades y reconocimientos.
Efectivamente, si comparamos los rostros de ambas imágenes analizadas, se puede percibir que la primera mujer de izquierda a derecha del grupo de angaites, es la misma persona que la segunda mujer arrodillada de izquierda a derecha en la imagen del grupo de hombres y mujeres frente a la empalizada de madera (Fig. 18). Por lo tanto, se puede asegurar que los sujetos retratados en estas fotografías,

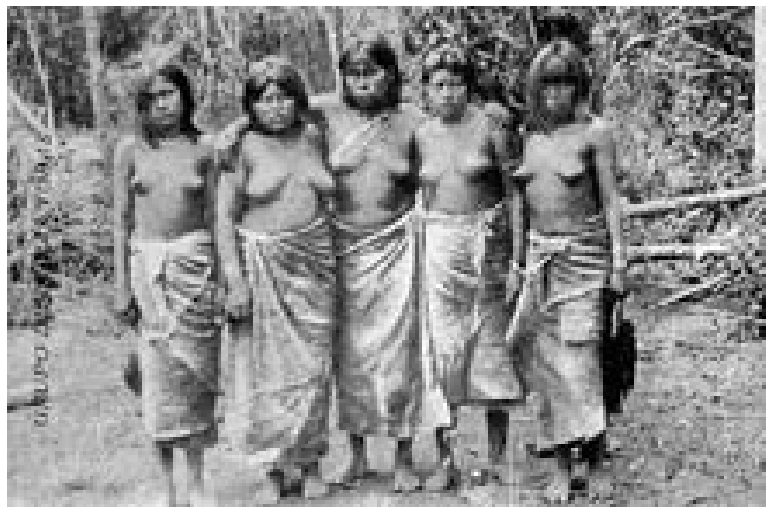

Fig. 15. "Lenguas (Brasil; Bolivia, Argentina, Paraguay, etc.)" Tarjeta Postal sobre una fotografía de Manuel de San Martín, editada por Guillermo Grüter. (Ca. 1910). Colección Müller Asunción, Paraguay. 


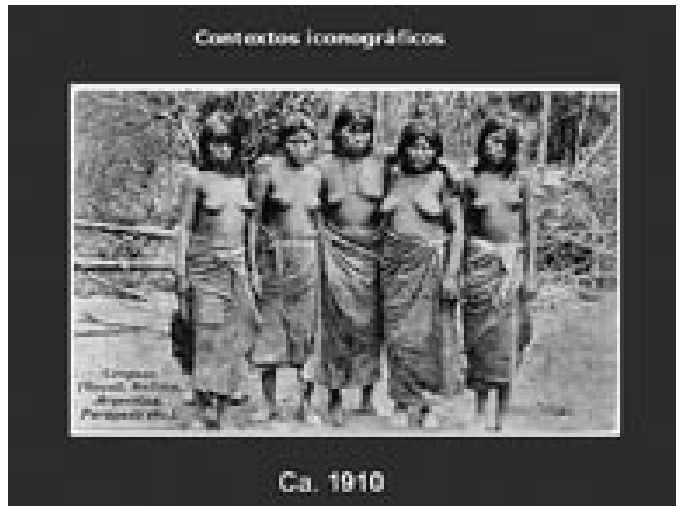

Fig. 16. "Grupo de indias Tobas". Tarjeta Postal sobre una fotografía de Manuel de San Martín publicada por el fotógrafo e impresor Alberto Ingimbert, (Ca. 1910).

Archivo CEDODAL, Buenos Aires, Argentina.

pertenecen al mismo grupo étnico identificado por San Martín como Angaites, habitantes del Chaco Paraguayo, haciendo evidente que la filiación étnica con que se etiquetan estas imágenes como Banda Yagan (Estrato visual A); Foto Grupo de Indios Ona: hombre mujeres y Grupo de mujeres onas (Estrato visual F); o su ubicación como "habitantes del extremo actual" (Estrato visual C) no corresponde en absoluto.

Estos son los diversos estratos iconográficos en los que hemos podido detectar la actualización de las dos fotografías que analizamos. El periplo de dichas fotografías fue dilatado en el tiempo, ya que se registra su publicación por casi cien años en diversos soportes y contextos iconográficos, bajo variadas etiquetas, pero que invariablemente establecen una identidad étnica específica de los retratados. Los sistemas culturales y discursivos en donde estas imágenes han sido actualizadas se relacionan con los ámbitos históricos y científico, donde los sujetos retratados han pasado a constituir una representación indiscutible de los indígenas fueguinos.

Cabe preguntarse entonces ¿mediante qué mecanismos, lecturas o interpretaciones los espectadores que consumieron y consumen estas imágenes hasta el día de hoy, llegaron a aceptar o deducir que los sujetos allí fotografiados podrían pertenecer al mundo de Tierra de Fuego? ¿Cómo aquellas concienzudas personalidades científicas de comienzos del siglo XX, quienes elaboraban los primeros estudios de nuestros pueblos originarios,

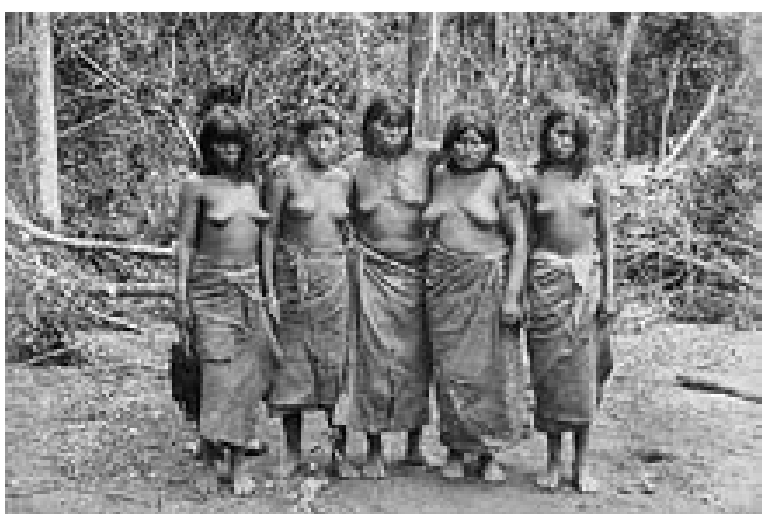

Fig. 17. "Indígenas de la tribu Angaites" Fotografía de Manuel de San Martín. Álbum de Vistas del Paraguay.

(1878). Archivo CEDODAL, Asunción, Paraguay.

no repararon en los cambios y desplazamientos de filiación "étnica" al que estaban sometiendo a estos sujetos retratados? Más aún, debiéramos preguntarnos ¿qué pasa hoy, cuando se continúan utilizando estas fotografías como imágenes representativas de la historia de Argentina y Chile, sin pensar que podrían existir identidades étnicas distorsionadas
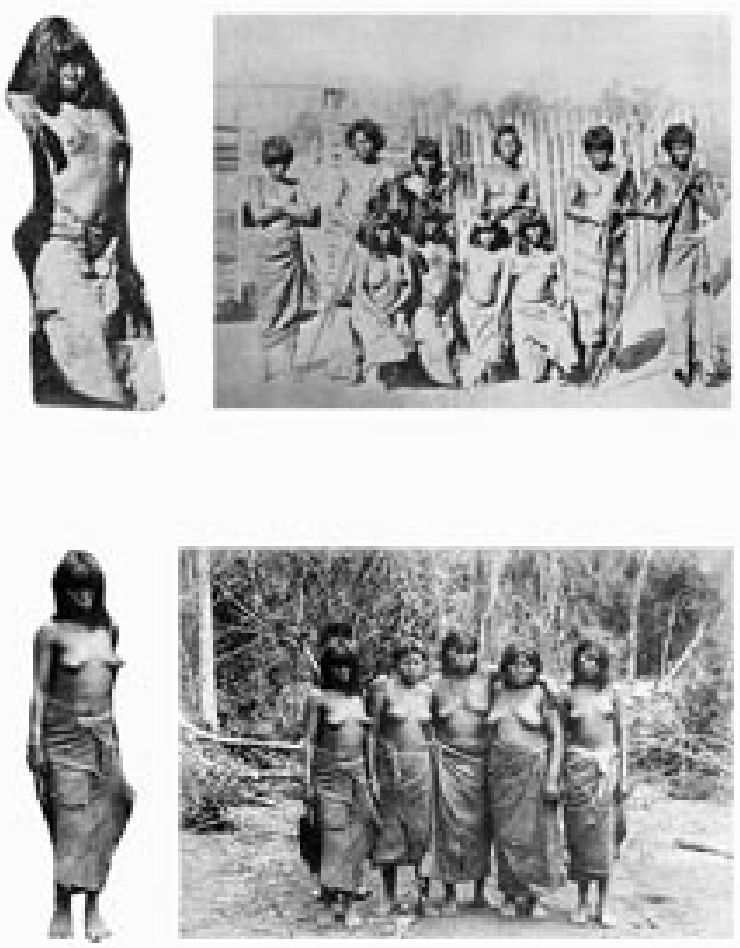

Fig. 18. Detalles y fotografías de los dos casos analizados. 
y desplazadas? La distancia entre el Chaco y la Tierra del Fuego es considerablemente extensa, pero esa distancia, evidentemente, no ha estado presente a la hora de interpretar y dar valor a estas dos imágenes fotográficas. La itinerancia de estas fotografías fue larga y prolongada y a pesar de las lentas comunicaciones de la época, estos indígenas estaban en el Chaco paraguayo y en la lejana Tierra del Fuego, a más 12.000 kilómetros de distancia casi simultáneamente.

\section{PASAPORTES DE VIAJES INDISTINTOS}

Considerando lo planteado hasta aquí, podemos sostener que las modalidades de construcción de las alteridades chaquenses y fueguinas, materializadas en los dispositivos y procedimientos visuales descritos, entregan un cierto tipo indígena (desnudo, armado de arco y flecha) que cumple visualmente con nuestro estereotipo de "bárbaro" o "salvaje". Así, estas imágenes llegan a representar casi un modelo de "lo bárbaro", porque coinciden con nuestras expectativas visuales de lo que suponemos un "estadio cultural" que adjudicamos a los orígenes de la humanidad: el indígena cazador-recolector. Bajo estas particularidades visuales estas dos fotografías llegan a constituirse en entidades atrapadas entre las exigencias ideológicas de un esteticismo visual propio de lo primitivo y un cientificismo que busca registrar un estadio cultural o un momento arcaico de la evolución de lo humano. Junto a muchas otras imágenes fotográficas, han pasado a integrar una imagen única, compacta y genérica de "lo bárbaro", en donde las marcas que hemos reconocido y descrito se han transformado en el visado de un pasaporte para entrar, salir y volver a radicarse en Argentina o Chile, como representantes de una etnia determinada.

Se puede decir que para el caso de las dos imágenes que analizamos, su valor no está en ser un objeto cultural, sino en la información que contienen en su superficie como fotografía, prevaleciendo por sobre el "dato" o antecedente que las constituye en documentos, los elementos básicos que parecen compartir los indígenas fotografiados. Estos "datos" visuales, es decir los sujetos desnudos o semi desnudos y la exhibición de artefactos que connotamos como propios, (arco, flechas y adornos corporales) son las marcas que las legitiman como representación indiscutible de un sujeto arcaico. Las fotografías de San Martín entonces, han trascendido una forma de configurar el mundo indígena del Chaco para constituirse en modelos de otros mundos lejanos y primitivos, como por ejemplo el de lo fueguinos.

Para nosotros como consumidores que llegamos a observar estas fotografías en los distintos contextos iconográficos donde han sido actualizadas, no resultan disidentes las diversas etiquetas que exhiben con lo representado visualmente, porque las marcas de lo bárbaro están contenidas allí. Y estas marcas son lo que le dan autenticidad indiscutible a lo representado, son las visas que les permiten una trashumancia desde el Chaco a Tierra del Fuego. Se expresa aquí entonces ciertas manipulaciones de la imagen con fines comerciales, editoriales y hasta académicos; políticas de representación y de (pre)sentación que devienen de procesos de prácticas materiales institucionalizadas visualmente, que al tiempo que atribuyen identidad(es) limitan, regulan y disciplinan. Corrobora esta afirmación el hecho que además de las dos imágenes analizadas, encontramos otros ejemplos de fotografías obtenidas en diversos lugares y fechas y que también operan como pasaportes abiertos, ya que los sujetos representados han sido sometidos a cambios y desplazamientos en su filiación étnica. Así, estas fotografías pasan a integrar una imagen única, compacta, genérica de "lo indio". Tanto sus marcas materializadas en sus indumentarias y artefactos como la configuración visual de la imagen fotográfica se transforman en las visas que le permiten viajar por el continente americano, asumiendo diversas identidades étnicas (Fig. 19).

\section{ENTRE LA NEGOCIACIÓN Y LA APROPIACIÓN: POLÍTICAS DE REPRESENTACIÓN VISUAL}

La actualización de estas imágenes en los diferentes contextos iconográficos descritos nos revela la existencia de diversas estrategias en las políticas de representación visual del indígena, que a pesar de la distancia cronológica y espacial, muestran ciertos elementos en común. Estas estrategias de representación se materializan en la visualidad de la imagen fotográfica, tal como le hemos visto, pero también en el discurso escrito que las acompaña -sobre todo el de las etiquetas- donde se hace 

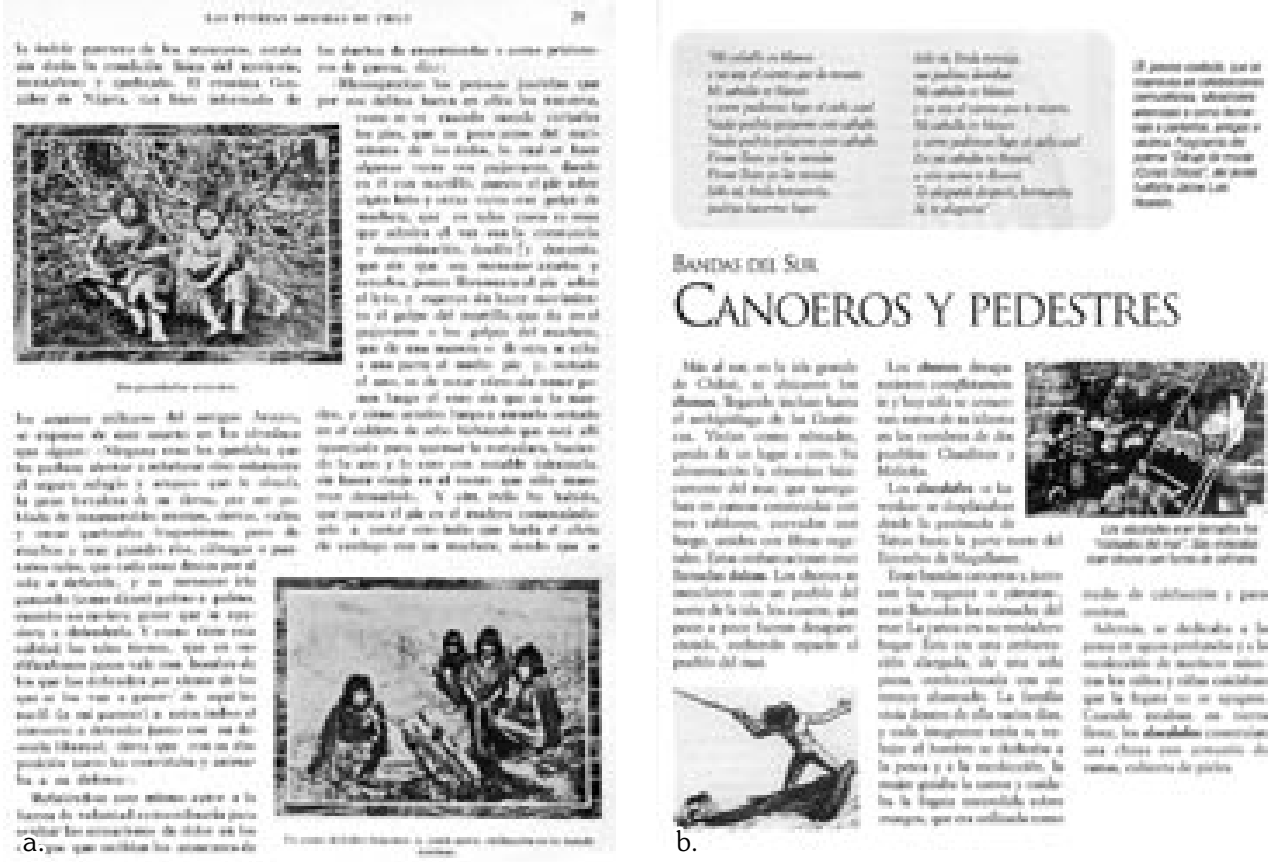

Bewrov ori Son.

\section{CANOEROS Y PEDESTRES}
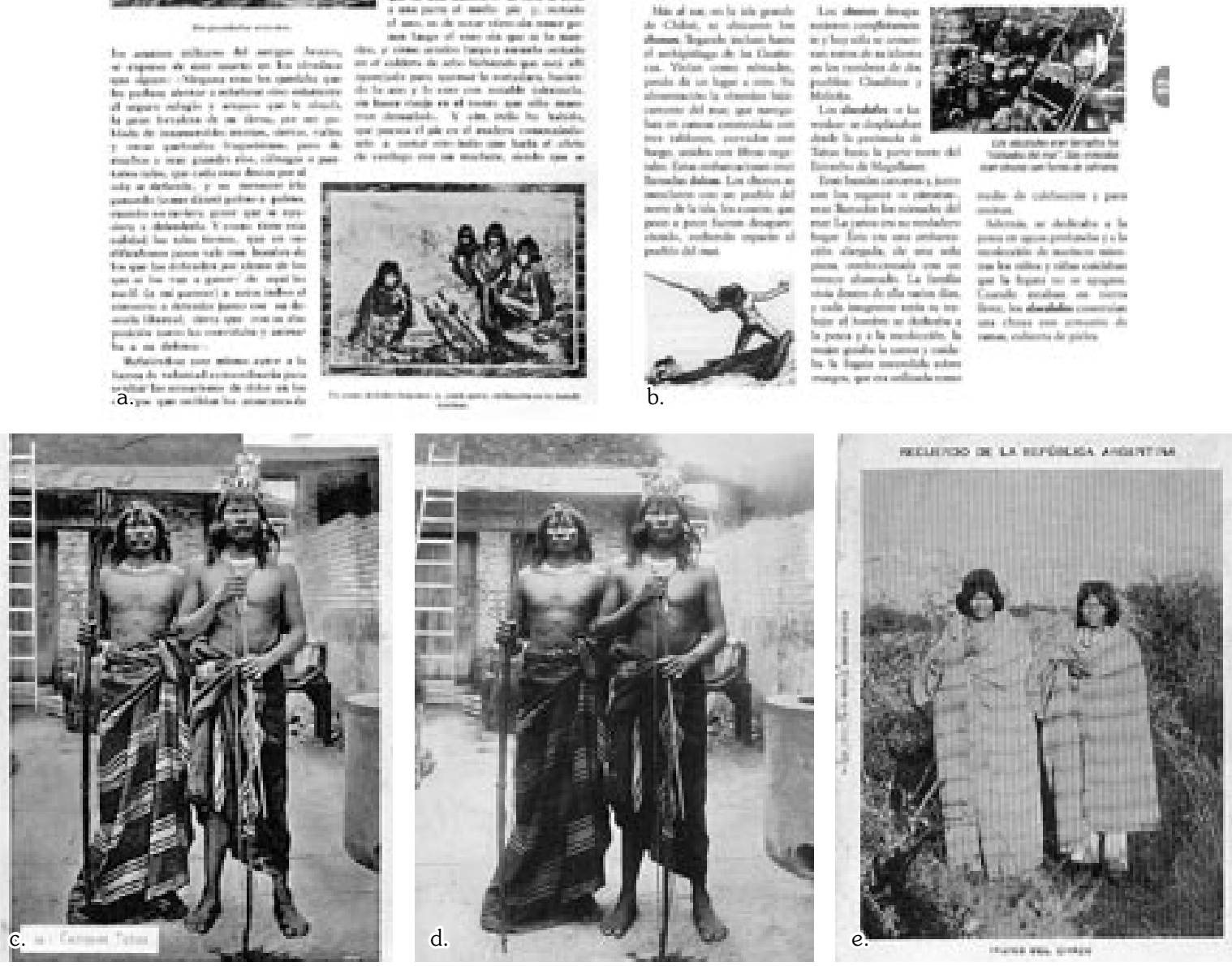

Fig. 19. a. "Dos pequeñuelos araucanos". Página № 29 del texto Fuerzas Armadas de Chile, Álbum Histórico (Empresa

Editora Atenas, 1928). Esta etiqueta atribuye una filiación mapuche a los dos niños fotografiados, sin embargo corresponde a una imagen de dos niños selk'nam, probablemente tomada por el fotógrafo Alberto María De Agostini, b. La etiqueta de esta fotografía señala "Los alacalufes eran llamados los 'nómades del mar'. Sus viviendas eran chozas con forma de colmena". Página № 33 del texto Comprensión de la Sociedad. 5to. Educación Básica. (Musalem, Molina y Enríquez, 2002). Corresponde a una fotografía tomada al interior de una ruka (vivienda) en la zona de Traiguén (IX Región de Chile) por Odber Heffer Bisset cerca de 1890 (Alvarado, Mege y Báez, 2001), c. "Caziques Tobas" Tarjeta Postal publicada por José Fresen en San Bernardino sobre una fotografía atribuida a Manuel de San Martín. (Ca. 1905), d. "Cacique Pucú, indios lenguas, Chaco (1900)". Página № 80 del texto "La fotografía en la historia Argentina. Tomo I". Lo interesante es que se incorpora una imagen a la historia de Argentina una imagen tomada a indígenas en el Paraguay. En la etiqueta de esta fotografía se le atribuye a estos dos personajes una pertenencia étnica diferente a la que apreciamos en la Tarjeta Postal, e. "Recuerdo de la República de Argentina. Indios del Chaco. Librería E. Meyer, Buenos Aires" (Ca. 1910). Esta etiqueta atribuye una filiación étnica genérica a estas dos mujeres retratadas, sin embargo ellas aparecen en algunas imágenes etiquetadas como indígenas de Tierra del Fuego. ¿Desde dónde y hacia dónde habrán realizado su trashumancia iconográfica? 
alusión a lo indígena o a una filiación étnica desde una perspectiva hegemónica, muy distante de una realidad social o cultural específica. En tal sentido el "espacio fotográfico" se proyecta en un nuevo "espacio semántico" en virtud de la relación establecida con el texto que la acompaña (Steegnev, 2002).

Así, podemos apreciar, cómo estos procesos de reapropiación, de manipulación y de construcción de identidades a partir de estas imágenes, fueron acompañados -y aún lo son- de un discurso escrito que hace alusión a "lo indígena" desde una perspectiva englobadota y totalizante de una realidad étnica y en permanente asociación a la dicotomía "civilización-barbarie", distante de una realidad social específica.

En este contexto, las políticas de representación visual se articulan en relación al mostrar y mostrar(se), donde puede apreciarse una "negociación" entre quien obtura la cámara y quien es retratado. De acuerdo al análisis que hemos realizado, esta práctica parecería hacerse muy difusa, haciendo evidente que imperan ciertos parámetros de representación, o de los "modos de ver" y de concebir la identidad del retratado desde uno de los agentes de la comunicación visual: el fotógrafo. Por otra parte, se puede apreciar cómo en las tempranas imágenes del Chaco paraguayo obtenidas por Manuel de San Martín y Guido Boggiani o en las primeras producciones del mundo fueguino tomadas por Jean - Louis Doze y Edmond - Joseph - Auguste Payen durante la Misión Francesa al Cabo de Hornos, los fotógrafos pretenden acercarse a nuevas maneras de representación, en tanto muestran a los indígenas en composiciones construidas -muchas veces según modelos occidentales- pero sin seguir los cánones estrictos de representación de los estudios antropométricos que predominaban en esta época. Estas fotografías dan cuenta de diversos sujetos, pero también aparecen tomas que van más allá y registran rostros, miradas y gestos que escapan a esta normada concepción del acto de fotografiar, trasgrediendo la pose antropométrica del retrato. Por ejemplo, una mirada atenta puede observar como en algunas tomas de los yámanas cuando abordan la embarcación de la Romanche, se inscribe una mirada frontal, donde el retratado pareciera participar más activamente en la negociación que todo acto fotográfico contiene; o las imágenes de Boggiani
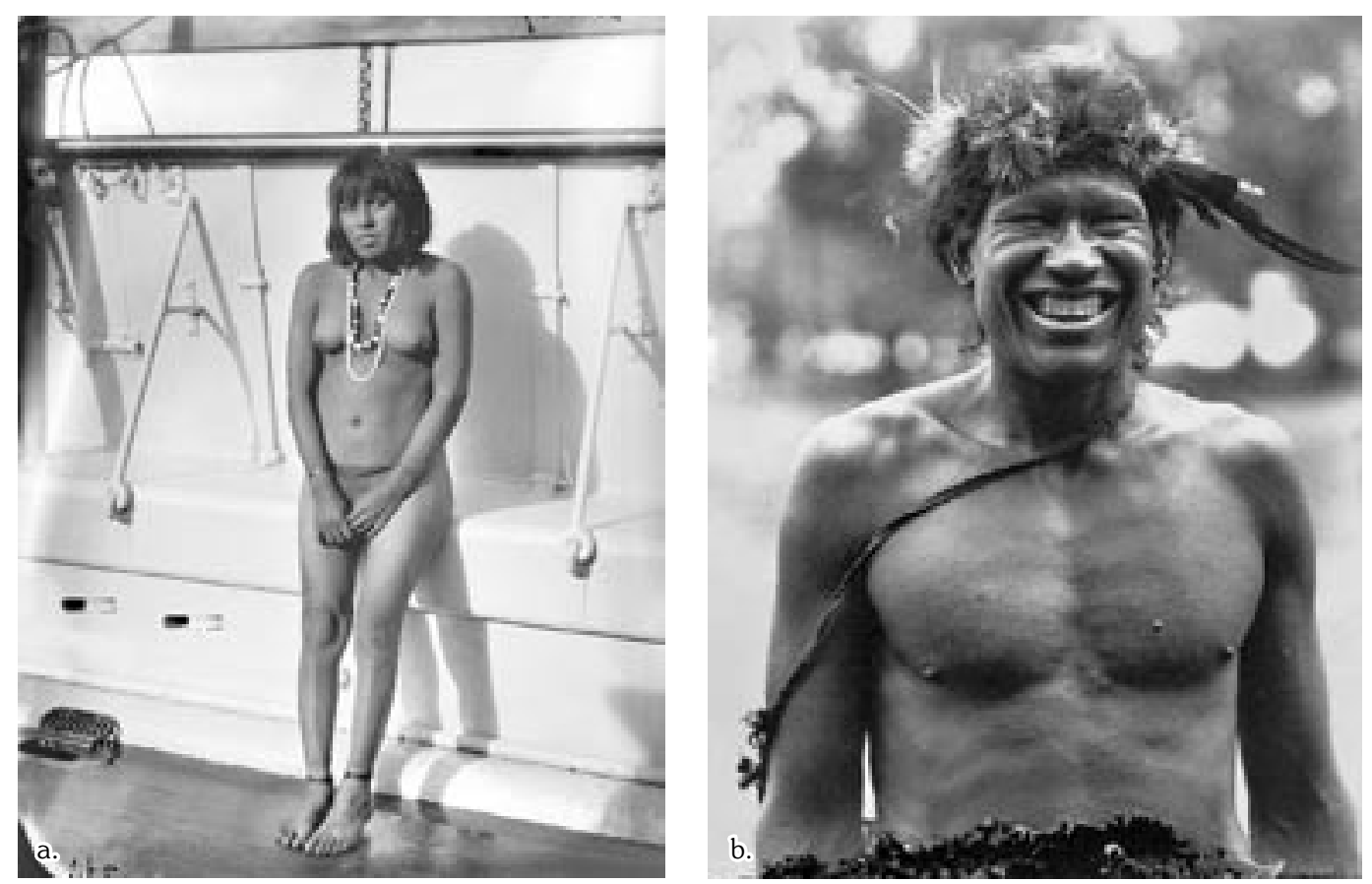

Fig. 20. a. Retrato. Fotografía de Jean L. Doze y Edmond J. A. Payen. Misión Científica al Cabo de Hornos (1882 - 1883). Photothèque du Musée de l'Homme, París, Francia, b. Retrato de Míllet. Indígena Chamacoco. en la ciudad Puerto 14 de Mayo, Paraguay. Fotografía de Guido Boggiani (1896 - 1901). Reproducida del texto "Guido Boggiani, fotógrafo" (Fri_y Fri_ova Editores, 1997). 
tomadas a los chamacocos, donde se asoma una amplia risa. Ambos ejemplos, entre otros, se nos presentan como una alteración de lo esperado en cuanto a la expresión facial del retratado de esta otredad, estableciéndose para el espectador, a través de estos pequeños gestos una nueva relación entre fotógrafo y fotografiado (Fig. 20).

De esta manera, estas fotografías suponen un espacio de negociación que emerge de un contacto cultural en un contexto histórico específico. Negociación que se vislumbra en las poses, las miradas, los escenarios, en suma, en la captura del sujeto y la escena. Esta dinámica en el acto de fotografiar en relación a ciertas políticas representacionales, no sólo está presente en los ejemplos analizados, sino también en muchas de las imágenes del corpus general de fotografías tomado como referente en nuestra investigación.

Como consecuencia de los trayectos de circulación y actualización de cualquier fotografía, se dan ciertos procesos de apropiación de la imagen. Esta apropiación ocurre o se produce más eficazmente dependiendo de los modos en que se presenta aquello que se (re)presenta, ya que al cambiar los contextos de circulación y lectura cambian los sentidos posibles del mensaje visual. La apropiación supone un acto de apropiar(se), derivando en cambios en el orden del significado que puede adquirir la imagen fotográfica como artefacto al presentarse en contextos diferentes, con descripciones y/o con intereses distintos a los que motivaron su producción. Por lo tanto, en esta apropiación a la que hacemos referencia, no hay un cuestionamiento a la originalidad o autenticidad de la imagen, sino a la alteración de significado que se transmite/construye como consecuencia del modo en que es presentada al espectador y por supuesto, el contexto iconográfico donde está siendo actualizada.

Parte de estos procesos lo hemos podido apreciar claramente en los dos ejemplos ampliamente analizados, donde los sujetos representados pueden llegar a asumir diversas identidades étnicas-visuales. Lo importante entonces, en cualquier análisis e interpretación con imágenes fotográficas, no es tanto preguntarse sobre la verosimilitud o autenticidad de la información que entrega como imagen, sino más bien intentar comprender y develar las prácticas de producción y de significación que preceden, rodean, condicionan y convierten cualquier fotografía en una superficie significativa, transformándola, como hemos visto con las imágenes chaqueñas y fueguinas, en un importante factor de configuración de identidades étnicas.

\section{BIBLIOGRAFÍA}

ALVARADO, MARGARITA; PEDRO MEGE y CHRISTIAN BÁEZ. 2001. Mapuche. Fotografías Siglos XIX y XX. Construcción y Montaje de un imaginario. Pehuén Editores. Santiago.

ALVARADO, MARGARITA y PETER MASON. 2001. La desfiguración del otro. Sobre una estética y una técnica de producción del retrato etnográfico. Revista Aisthesis 34: 242 -257. Instituto de Estética, Pontificia Universidad Católica de Chile. Santiago.

ALVARADO, MARGARITA; CAROLINA ODONE; FELIPE MATURANA y DANAE FIORE (editores). 2007. Fueguinos. Fotografías Siglos XIX y XX. Imágenes e imaginarios del fin del mundo. Pehuén Editores. Santiago.

BARTHES, RONALD. 1982. La cámara lúcida. Editorial Gustavo Gilli S.A., Barcelona.

BATCHEN, GEOFFREY. 2004. Arder en deseos. La concepción de la fotografía. Editorial Gustavo Gilli S. A., Barcelona.

BAURET, GABRIEL. 1999. De la fotografía. Biblioteca de la Mirada, Editorial La Marca, Buenos Aires.

BECEYRO, RAÚL. 2003. Ensayos sobre fotografía. Editorial Paidós, Buenos Aires.

BURKE, PETER. 2001. Visto y no visto. El uso de la imagen como documento histórico. Editorial Crítica. Barcelona.

CAÑAS PINOCHET ALEJANDRO. 1911. La geografía de Tierra del Fuego y noticias de la antropología y etnografía de sus habitantes. Trabajos III Sección de Ciencias Naturales, Antropológicas y Etnológicas, Tomo I, Carlos Porter Editor. Imprenta, Litografía y Encuadernación 'Barcelona', Santiago.

CATÁLOGO. Fotografía Latinoamericana. 2001. Colección CEDODAL. Buenos Aires.

CONCHA, JOSÉ PABLO. 2004. Más allá del referente, fotografía. Del índex a la palabra. Colección Aisthesis 30 años № 3. Instituto de Estética. Pontificia Universidad Católica de Chile. Santiago.

DUBOIS, PHILIPPE. 1986. El acto fotográfico. De la recepción a la representación. Ediciones Paidós. Barcelona. Santiago.

EDWARDS, ELIZABETH (editor). 1992. Anthropology \& Photography. $1860-1920$. Yale University Press. New Haven and London. 
EMPRESA EDITORA ATENAS (Compilado y Editado). 1928. Fuerzas Armadas. Álbum Histórico. Empresa Editora Atenas, Santiago.

FLUSSER VILEM. 1990. Hacia una filosofía de la fotografía. Editorial Trillas. Ciudad de México.

FRI_, PAVEL e YVONNA FRI_OVA (editores). 1997. Guido Boggiani, zoógrafo. Nakladatelství Titanic. Praga.

GIORDANO, MARIANA. 2004. Discurso e imagen sobre el indígena chaqueño. Colección Diagonios, Ediciones Al Margen. La Plata.

2002. "Las múltiples facetas de Guido Boggiani." En: Boggiani y el Chaco. Una aventura del Siglo XIX. Publicación del Museo de Arte Hispanoamericano "Isaac Fernández Blanco". Año 5, №15. Buenos Aires, pp.31-47.

2003. Convenciones iconográficas en la construcción de la alteridad. Fotografías del indígena del Gran Chaco. En: II Congreso Internacional de Teoría e Historia de las Artes-X Jornadas del CAIA: Discutir el canon. Tradiciones y valores en crisis, 147-160. CAIA, Buenos Aires.

LLOYD, REGINALD. 1915. Impresiones de la República de Chile en el Siglo XX. Historia, gente, comercio, industria. Jas Truscott and Son Ltd. Artistas Impresores, Londres,

MASOTTA, CARLOS. 2001. Cuerpos dóciles y miradas encontradas. Límites del estereotipo en las postales de indios argentinas (1900-1940). IV Congreso Chileno de Antropología. Universidad de Chile. Revista Chilena de Antropología Visual № 3, Santiago (formato electrónica)

MEDINA, JOSÉ TORIBIO (Editor). 1910. La Araucana de D. Alonso de Ercilla y Zúñiga. Edición del Centenario. Imprenta Elzeveriana, Santiago.

MUSALEM, NELLY, PAULA MOLINA y MARÍA ENRÍQUEZ. 2002. Estudio y Comprensión de la Sociedad. 5to. Educación Básica. Editorial Mc Graw Hill, Santiago.
MONTECINOS SONIA, FOESTER, ROLF, y ANGELICA WILSON. 1993. Reflejos de luna vieja. Arancibia Hermanos y Cía. Santiago.

ODONE, CAROLINA y PETER MASON (editores). 2003. Doce miradas sobre Selk'nam, Yaganes y Kawesqar. Editorial Taller Experimental Cuerpos Pintados. Santiago.

PENHOS, MARTA. 1995a. La fotografía del siglo XIX y la construcción de una imagen pública de los indios. IV Jornadas de Teoría e Historia de la Artes. El arte entre lo público y lo privado, 109-125. Facultad de Filosofía y Letras, Buenos Aires.

1995b. Retratos de indios y actos de representación Memoria del $4^{\circ}$ Congreso de Historia de la Fotografía en la Argentina. Buenos Aires.

POOLE, DEBORAH. 1997. Vision, race and modernity: a visual economy of the Andean image world. Princeton University Press, Princeton.

QUIROZ, DANIEL. 1993. Fotografías, sombras, espectros. Revista Museos 17: 22. Santiago.

SAMUEL, RAPHAEL. 2000. El ojo de la Historia. En: Entrepasados Revista de Historia 18/19: 95-106. Buenos Aires.

SOULANGES, FRANÇOIS. 2005. Estética de la fotografía. La Marca. Buenos Aires.

STEEGNEV, VALERY. 2002. El texto en el espacio fotográfico. En: YATES, STEVE (editores). Poéticas del espacio. Gustavo Gilli, Barcelona, pp. 95-106.

TAGG, JOHN. 2005. El peso de la representación. Editorial Gustavo Gilli, Barcelona.

VEZUB, JULIO. 2002. Indios y soldados. Las fotografías de Carlos Encina y Edgardo Moreno durante la Conquista del Desierto. El Elefante Blanco. Buenos Aires. 